\title{
Fabrication and laboratory-based performance testing of a building-integrated photovoltaic-thermal roofing panel
}

\author{
Fangliang Chen, Huiming Yin* \\ Department of Civil Engineering and Engineering Mechanics, Columbia University, \\ 610 Seeley W. Mudd 500 West 120th Street,
}

New York, NY 10027

\begin{abstract}
A building integrated photovoltaic-thermal (BIPVT) multifunctional roofing panel has been developed in this study to harvest solar energy in the form of PV electricity as well as heat energy through the collection of warm water. As a key component of the multifunctional building envelope, an aluminum/high-density polyethylene (HDPE) functionally graded material (FGM) panel embedded with aluminum water tubes has been fabricated through the vibrationsedimentation approach. The FGM layer gradually transits material phases from well-conductive side (with aluminum dominated) to another highly insulated side (with HDPE). The heat in the PV cells can be easily transferred into the conductive side of the FGM and then collected by the water flow in the embedded tubes. Therefore, the operational temperature of the PV cells can be significantly lowered down, which recovers the PV efficiency at high temperatures. In this way, the developed BIPVT panel is able to efficiently harvest solar energy in the form of both PV electricity and heat. The performance of a prototype BIPVT panel has been evaluated in terms of its thermal efficiency via warm water collection and PV efficiency via the output electricity. The laboratory test results demonstrate that significant energy conversion efficiency improvement can be achieved for both electricity generation and heat collection by the presented BIPVT roofing system. Overall, the performance indicates a very promising prospective of the new BIPVT multifunctional roofing panel.
\end{abstract}

Keywords: Building integrated photovoltaic/thermal (BIPVT) system; Building envelope; Roofing panel; Solar energy; Energy conversion; Functionally graded materials (FGM).

\begin{tabular}{|c|c|c|c|}
\hline \multicolumn{2}{|c|}{ Nomenclature } & $E_{I N}$ & Absorbed irradiance by the BIPVT panel \\
\hline \multirow[t]{2}{*}{ A } & Total area of the BIPVT panel and the & $E_{p v}$ & Output electricity \\
\hline & frame & $E_{M A X}$ & Maximum output electricity \\
\hline$C_{\text {water }}$ & Specific heat capacity of water & $E_{T}$ & Theoretical electricity \\
\hline$\Delta T_{\text {water }}$ & Temperature increase of the outlet water & $P$ & Electricity power \\
\hline & over the inlet water & $P_{\max }$ & Maximum electricity power \\
\hline$\Delta T_{\text {panel }}$ & $\begin{array}{l}\text { Temperature decrease of the BIPVT } \\
\text { surface }\end{array}$ & $\begin{array}{l}Q_{\text {water }} \\
I_{R}\end{array}$ & $\begin{array}{l}\text { Useful collected heat by water } \\
\text { Irradiance intensity }\end{array}$ \\
\hline
\end{tabular}




$\begin{array}{llll}I_{M P} & \text { Max power current } & \text { BIPV } & \text { building-integrated photovoltaic } \\ I_{S C} & \text { Short circuit current } & \text { BIPVT } & \text { building integrated photovoltaic thermal } \\ V_{M P} & \text { Max power voltage } & \text { DPD } & \text { dissipative particle dynamics } \\ V_{O C} & \text { Open circuit voltage } & \text { FF } & \text { Fill Factor } \\ \text { FF } & \text { Fill factor } & \text { FGM } & \text { functionally grated material } \\ m_{\text {water }} & \text { Mass of the flowing water per second } & \text { HDPE } & \text { high density polyethylene } \\ \eta_{\text {thermal }} & \text { Ratio of the collected thermal energy } & \text { IBC } & \text { International Building Code } \\ & \text { with respect to the irradiance energy } & \text { I-V } & \text { current-voltage } \\ & \text { absorbed by the panel, } & \text { NEC } & \text { National Electric Code } \\ \eta_{p v} & \text { Electricity conversion efficiency } & \text { PV } & \text { photovoltaic } \\ \eta_{T} & \text { Total energy efficiencies } & \text { P-V } & \text { power-voltage } \\ & & \text { PVC } & \text { polyvinyl chloride } \\ \text { Abbreviations } & \text { PVT } & \text { photovoltaic thermal } \\ \text { Al aluminum } & \text { TE } & \text { thermoelectric }\end{array}$

\section{Introduction}

The U.S. Department of Energy reported that building sectors consume more than $40 \%$ of the total energy and $73 \%$ of the total electricity produced in the U.S., and produce a significant fraction of non-renewable and non-recyclable building materials [1]. To reduce building energy consumption and greenhouse gas emissions, new technologies of efficient and renewable energy supply systems are in high demand. Solar energy is the most abundant renewable clean energy source, and modern technology can harness solar energy for a variety of uses, including generating electricity, providing light for a comfortable interior environment, and heating water for residential, commercial, or industrial use [2]. As solar energy technologies have advanced in recent years, integrated technologies for harvesting solar energy into building sectors, such as buildingintegrated photovoltaic (BIPV) systems [3-7], building-integrated solar thermal (BIST) systems [8-10], or building-integrated photovoltaic/thermal (BIPVT) systems [11-14], have evolved as viable technologies to improve building energy performance and to reduce environmental effects $[15,16]$. Those integrated systems replace parts of the conventional building materials and the components in the climate envelope of buildings, such as facades and roofs, and simultaneously serve as both a building envelope material and power generator [17-19]. Compared with most conventional non-integrated systems, in addition to the power supply function, the integrated system offers several advantages: (1) there is no need for the allocation of land or facilitation of the PV system; (2) it does not require additional assembly components such as brackets and rails; and (3) it thus achieves significant savings in terms of the total building materials costs and associated labor fees [20,21].

Today, most photovoltaic (PV) modules in production are based on crystalline silicon wafer technologies. The electricity conversion efficiency of silicon solar modules available for commercial application is about $12-20 \%$ [22]. However, more than $85 \%$ of the incoming solar energy is either reflected or absorbed as heat energy [23]. Consequently, the working temperature of the solar cells increases considerably after prolonged operations. Solar panel temperature is one of the important factors that affects electricity conversion efficiency, most solar cells show a heatrelated performance loss of about $0.4-0.5 \% /{ }^{\circ} \mathrm{C}[24]$. Without a cooling system, in-service surface temperatures are commonly $40-50^{\circ} \mathrm{C}$ above ambient temperature, resulting in $16-25 \%$ reductions 
in electricity generation or malfunction beyond the operational temperature range [25]. The rise in PV temperature not only reduces electricity generation, but also reduces the life-span of the module itself. Therefore, a technique that is able to cool the solar panel is in high demand in order to improve both the energy efficiency and service-life of the solar panels.

If a BIPV system is properly designed, the cooling load of the building envelope in which PV modules are integrated into can be eliminated, and the heat energy can be collected by the flow of air or a liquid, this is the fundamental design concept of a BIPVT system. The BIPVT system appears as an exciting new technology as it merges photovoltaic and thermal systems, simultaneously harvesting both electrical and the thermal energy [16]. The most common BIPVT systems are realized through a heat transfer fluid in an open-loop (usually air) [26-28] or closedloop (usually liquid) configuration [29-32]. Chen et al [33] designed an air-based open-loop BIPVT system that was thermally coupled with a ventilated concrete slab. Their field test results indicated that a typical efficiency of about $20 \%$ for thermal energy collection can be obtained, and as a result the annual space heating energy consumption of the house is about $1600 \mathrm{kWh}$, which is about 5\% of the national average. A prototype open loop air-based BIPVT system with a single inlet [27] was experimentally studied in a full scale solar simulator. It was found that, in an openloop air-cooled BIPVT system with large-scale PV areas covering complete roof or façade surfaces, the temperature of PV arrays can rise to high values (exceeding $70^{\circ} \mathrm{C}$ ), resulting in a significant decrease in electrical efficiency and degradation of PV panels with time. Thus it is desirable to enhance heat removal from the PV panels by using multiple inlets instead of a single inlet. For this purpose, they further designed a two-inlet BIPVT system [28]. Their test results indicated that an equivalent two-inlet system with frameless PV panels can increase the thermal efficiency by $5 \%$ compared to a conventional one-inlet system.

Generally, the closed-loop configuration with liquid is more efficient than the open-loop with air as heat transfer fluid due to the high thermo-physical properties of liquid compared to air [34]. Within the category of rooftop or roof added BIPVT systems, based on the closed loop configuration, Corbin and Zhai [31] designed a BIPVT with thermal and combined (thermal plus electrical) efficiencies of about $19 \%$ and $34.9 \%$, respectively. Their test results showed that the PV efficiency of their BIPVT can be raised by 5.3\% and the collected warm water was suitable for domestic utlization. Ibrahim et al. [35] developed a BIPVT roof system with a spiral flow copper absorber attached at the bottom of the PV modules on the roof. It was reported that an energy efficiency of about $55 \%-62 \%$ can be achieved for a BIPVT system. Buker et al. [36] recently developed a BIPVT roof collector combined with a liquid desiccant enhanced indirect evaporative cooling system. Their experimental results showed that the BIPVT roof collector is capable of providing about $3 \mathrm{~kW}$ of heating, $5.2 \mathrm{~kW}$ of cooling power and $10.3 \mathrm{MWh} /$ year of power generation, respectively. In addition, the overall power efficiency data also shows that the power energy performance of PV modules can be improved by $10.7 \%$ due to achieved collector cooling as the cold water flow creates a passive cooling effect and partially removes the waste heat from the PV modules. Currently, most closed-loop BIPVT systems employ water tubes for cooling and thermal energy collection. Normally, the water tubes are embedded in insulation materials and covered by absorber materials in contact with the PV elements above[37]. These designs commonly exhibit poor heat conduction due to the small contact area between the absorber and water pipes.

A recent study [38] has shown that there is great potential to harvest solar energy efficiently by developing a BIPVT roofing panel with functionally graded materials (FGMs) as a key component. The purpose of the proposed FGM layer is to function as a lightweight layer of a solar roofing panel that has a varying thermal conductivity in the thickness direction. Our research group 
has been dedicated to realize this unique BIPVT technology for several years. Originally, a hybrid solar panel assembled with PV cells and thermoelectric (TE) modules was developed to harvest both electricity and warm water [39], but it was found eventually that the integration of the TE modules was not able to provide any benefits over PV cells alone. Subsequently, the TE modules were excluded and the heat transfer [40] and overall performance [38] of the BIPVT were simulated and evaluated respectively. Note that in the original design, the solar panel was restricted to a small size $(304.8 \mathrm{~mm} \times 304.8 \mathrm{~mm})$ hindered by the fabrication method of the FGM panel, which was fabricated by simply laying mixed powders with different mixing ratios of HDPE and Al particles into different layers to form a multiple layer composite panel $[39,40]$. It was observed that using this method, continuous gradation cannot be achieved in the final product, resulting in a low heat transferring efficiency from PV cells to the composite panel. Moreover, it is difficult to both precisely control such a layering method and to assure the quality of the final product, as a result it is hard to scale the method for larger sample fabrication. It was also observed that the straight water tubes distributed in parallel in the FGM panel were only able to effectively cool down part of the solar panel, while the other part close to the outlet water tube was still at a relatively high temperature [40], leading to an unevenly distributed temperature and thus counteracting its improved efficiency.

Recently, a novel combined vibration and sedimentation approach has been developed with an aim towards mass production of the FGM and its quality control [41]. With this novel fabrication method, standardized $609.6 \mathrm{~mm} \times 609.6 \mathrm{~mm}$ FGM panels with perfect continuous gradation have been fabricated. FGMs are heterogeneous materials which are composed of two or more phases with different properties, sizes and shapes. In a typical FGM, the volume fractions of the constituents vary gradually, resulting in a composite with continuously graded material properties, such as mechanical, electrical, and thermal parameters, at the macro level [42,43]. Such a distinctive feature of the FGMs can be exploited to obtain properties that are not offered by conventional materials. The final production of our previously developed FGM [41] gradually transits material phases from being metal dominated (aluminum) to a polymer material. Water tubes are embedded in the top part of the FGM layer, where the high aluminum concentration creates a high thermal conductivity so that the heat that flows from the surface can be immediately transferred in all directions to water tubes, yet be insulated by the bottom part of polymer layer. Based on these FGM panels, a multifunctional BIPVT roofing panel has been realized and hereby presented in this study. In order to remove the heat within the panel more uniformly and to cool down the solar panel more efficiently, water tubes with a double-serpentine shape were designed and embedded in the FGM panel. The development and performance evaluation of the proposed BIPVT roofing panel are presented in the following sections. Section 2 provides the fabrication procedures for the FGM panel with the recently developed combined vibration and sedimentation approach, and introduces the design, fabrication and integration of a prototype BIPVT panel. Section 3 evaluates the performance of the BIPVT panel in terms of its thermal efficiency via warm water collection and PV efficiency via the electrical output. Based on the laboratory measurements and materials used, Section 4 estimates the material and construction costs of the present BIPVT roofing panel for different roof areas. Finally, some conclusive remarks are provided.

\section{Design and fabrication of a prototype BIPVT roofing panel}




\subsection{Design and manufacture of a novel FGM panel}

In recent years, a sedimentation method for FGM manufacturing has been developed by the authors [44,45], which uses a suspension to create the graded microstructure of the mixture. In this method, aluminum ( $\mathrm{Al}$ ) particles and high density polyethylene (HDPE) powder are mixed thoroughly with ethanol to fabricate FGM layers in the laboratory. Because Al and HDPE have significantly different specific gravities ( 2.7 and 0.95 , respectively) and due to the particle size distribution (50-150 $\mu \mathrm{m}$ and 5-30 $\mu \mathrm{m}$, respectively), the two types of powders will fall down at different velocities and thus create a graded microstructure. When a desired graded microstructure forms, the ethanol is filtered out for reuse. The sedimentation process has been modeled by Stokesian dynamics and dissipative particle dynamics (DPD) [45]. Such a sedimentation method was shown to be effective in fabricating small size samples; however, it consumes large amount of ethanol and thus turns out to be cost inefficient. Later, a small size $(304.8 \mathrm{~mm} \times 304.8 \mathrm{~mm})$ FGM panel was fabricated by simply laying mixed powders with different mixing ratios of HDPE and Al particles into different layers to form a multiple layer composite panel [38-40]. However, it shows that no continuous gradation can be obtained by this method, and it will be difficult for such a simple layering method to control and assure the final product quality and it is hard to scaleup for larger sample fabrication.

To improve the fabrication efficiency and quality assurance, a novel combined vibration and sedimentation approach has been recently developed toward mass production and improving the quality control of the FGM [41]. The proposed FGM was made using coarse aluminum particles (with a size ranging from 100 to $600 \mu \mathrm{m}$ with a median size of $300 \mu \mathrm{m}$ ) and the finer HDPE powder (with a size ranging from 1 to $100 \mu \mathrm{m}$ with a median size of $25 \mu \mathrm{m}$ ). A mix design for the FGM with an appropriate volume ratio of $\mathrm{Al}$ to HDPE of 1:3 was determined after a series of tries and comparisons, and the ethanol added for the mixing was chosen by the weight ratio of ethanol to the mixed powder as $28 \%$ [41]. The reason to use ethanol instead of water is twofold: (a) because of water's specific gravity is between those of Al and HDPE, it is often leads to laminated deposition instead of graded microstructure; and (b) when the sedimentation process is long (more than 10 hours), a chemical reaction between $\mathrm{Al}$ and water has been observed, which produces hydrogen and alumina.

Figure 1 summarizes the design and fabrication procedure of the FGM panel. The measured component materials based on the mix design were mixed in a Hobart mixer for about 6 minutes with a pause at every 2 minutes (Figure 1(a)). The mixed suspension was then transferred into an aluminum mold clamped on a Syntron vibrating table (Model VP-51) as shown in Figure 1(b). The mold containing the mixed suspension was vibrated for 30 seconds at a power amplitude of 80 and frequency of $75 \mathrm{~Hz}$. Thereafter, the mixed suspension was kept in the mold allowing further sedimentation of Al particles in the suspension. During this process, the ethanol will completely drained off in about 24 hours. By heating up the graded powder mix in a vacuum oven, the HDPE powder will melt so as to form a composite of Al particles dispersed in the HDPE matrix with a graded microstructure Figure 1(c). The air voids in the melted composite which resulted from particle mixing were degassed by applying the vacuum and the sample was cured in the vacuum oven at $170^{\circ} \mathrm{C}$ for about 1 hour. The whole set up was turned off and the FGM sample was removed from the mold when the temperature cools down to room temperature. The cross section of one sample element cut from the FGM panel is shown in Figure 1(d), which shows that a wellcontrolled graded FGM was achieved by the proposed combined vibration and sedimentation approach. 

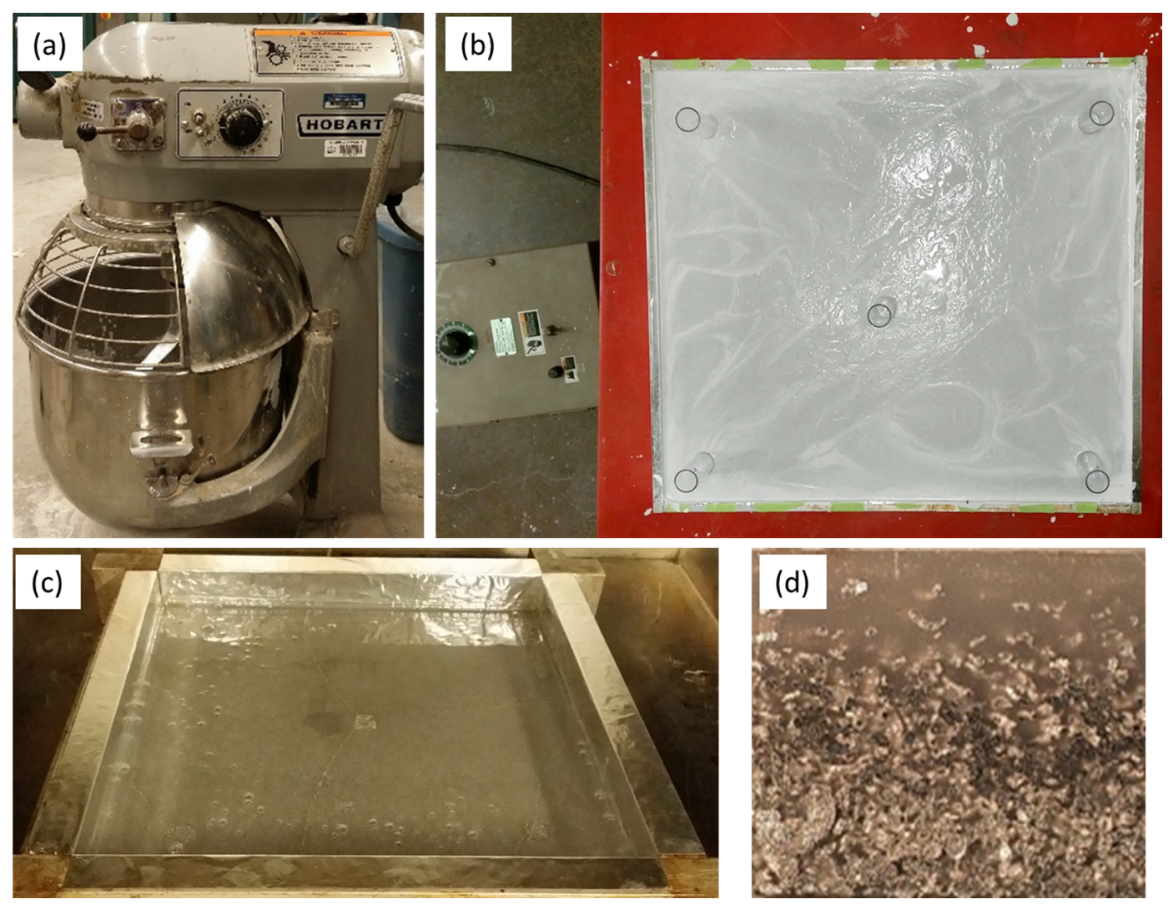

Figure 1 Fabrication process of the FGM panel: (a) mixing of Al particles and HDPE powder with ethanol; (b) sedimentation and vibration of mixed suspension; (c) degassing of the dried mixture in vacuum oven; and (d) cross-section of the cured FGM.

After the optimized manufacturing parameters of the FGM panel was acquired, a $609.6 \mathrm{~mm} \times$ $609.6 \mathrm{~mm}$ prototype FGM panel with embedded water tubes was fabricated by the combined vibration and sedimentation approach. The purpose of the designed double serpentine shape of the water tubes as shown in Figure 2(a) is to remove the heat within the panel more uniformly and thus it keeps the temperatures of the panel's surface much more uniform. When the FGM panel was cured and taken out from the vacuum oven, it was seamlessly glued to a fire-retardant plywood through a moisture resistant epoxy adhesive as shown in Figure 2(b). The integrated FGM panel and plywood substrate will be then sprayed by a thin layer of moisture-resistant resin, which reacts chemically with the natural moisture in the wood, creating a highly moisture resistant substance similar to polyurethane. Due to the gradual change of the proportion of materials, only a small amount of aluminum powder is needed. This reduces the cost of the panel as the aluminum material is relatively expensive. The heat absorbing layer and insulation layer in traditional PVTs can be replaced by one FGM layer that integrates the high thermal conductivity in the top part and low thermal conductivity in the bottom. Since the volume fraction of Al particle continuously varies in the thickness direction, the thermo-mechanical property distribution changes smoothly, and avoids the thermal stress concentration across layers and increases the structural integrity and durability of the panels. 

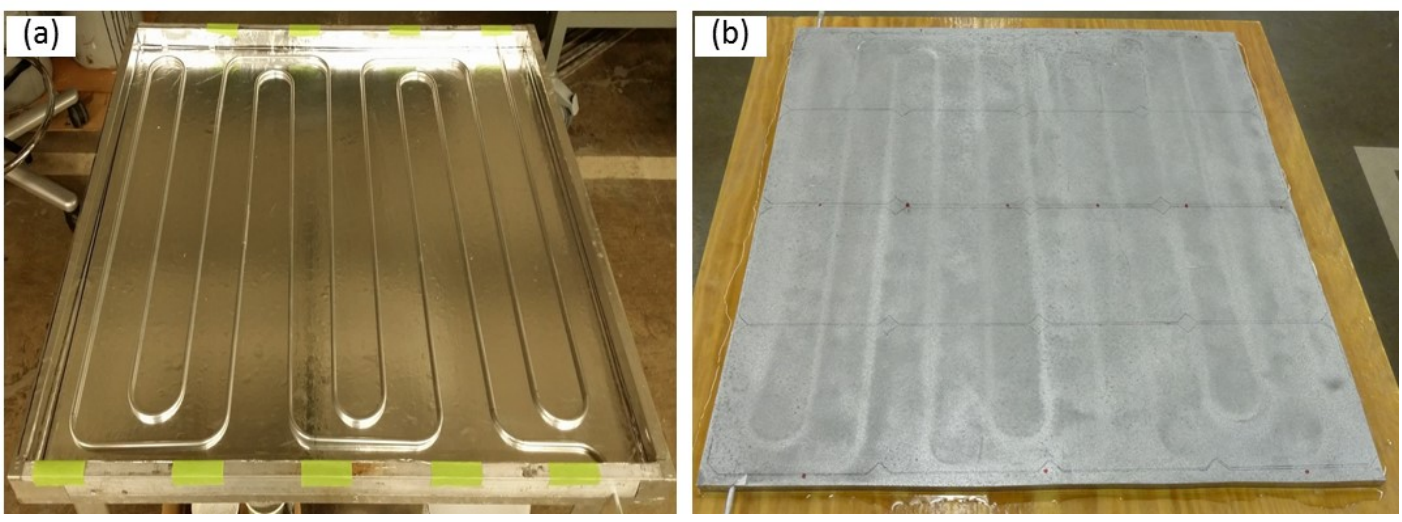

Figure 2 Embedment of water tube and integration of substrate: (a) double serpentine shape of water tubes in the casting mold; and (b) assembling of FGM panel with structural substrate.

\subsection{Assembling of the BIPVT}

After polishing the metal rich surface of the FGM, 16 pieces of mono-crystalline silicon PV cells (with a maximum efficiency of $18.8 \%$ and a max power of 2.88 Watts) with dimensions of $127 \mathrm{~mm} \times 127 \mathrm{~mm}$ were mounted onto the FGM layer by a thermal conductive adhesive. In order to generate a uniform bond surface between the FGM and the PV cells and avoid any residual adhesive overflow to the cell surfaces, 16 adhesive regions with dimensions of $101.6 \mathrm{~mm}$ $\times 101.6 \mathrm{~mm}$ were prepared by peeling off the pre-attached tapes from the uniform one that was applied on the FGM panel (Figure 3(a)). The 16 PV cells were gently attached onto the adhesive and a slight uniform pressure was applied on each PV cell. When the adhesive was cured after 24 hours, the pressure was removed and the mounted PV module was obtained, which is shown in Figure 3(b).

In field application, a transparent protective waterproofing layer will be further mounted on the BIPVT panel to protect the power generating elements and underlying building materials from external environmental distress such as moisture migration, surface wear and impact from dust, wind, storm, etc. A schematic illustration of the developed BIPVT panel is shown in Figure 3(c), where the FGM layer gradually transits material phases from a well-conductive side (aluminum dominated) attached to a photovoltaic (PV) solar cell, to a highly insulated side (polymer materials) bonded to a structural substrate. The water tubes are embedded in the top part of the FGM layer, where the high aluminum concentration creates a high thermal conductivity so that heat can be immediately transferred to the water tubes from all directions, yet be insulated by the bottom part of FGM layer and the thermal insulation plywood. The substrate provides support for mechanical loading and functions as thermal insulation for the building envelope. The multilayered solar panel is designed in such a way that layers with potentially shorter life expectancies can be easily replaced or removed from the design based on the sustainability measurement criteria, which can be applicable to other sustainable building materials and systems for building construction. The detailed fabrication procedures are illuminated in Figure 4. 

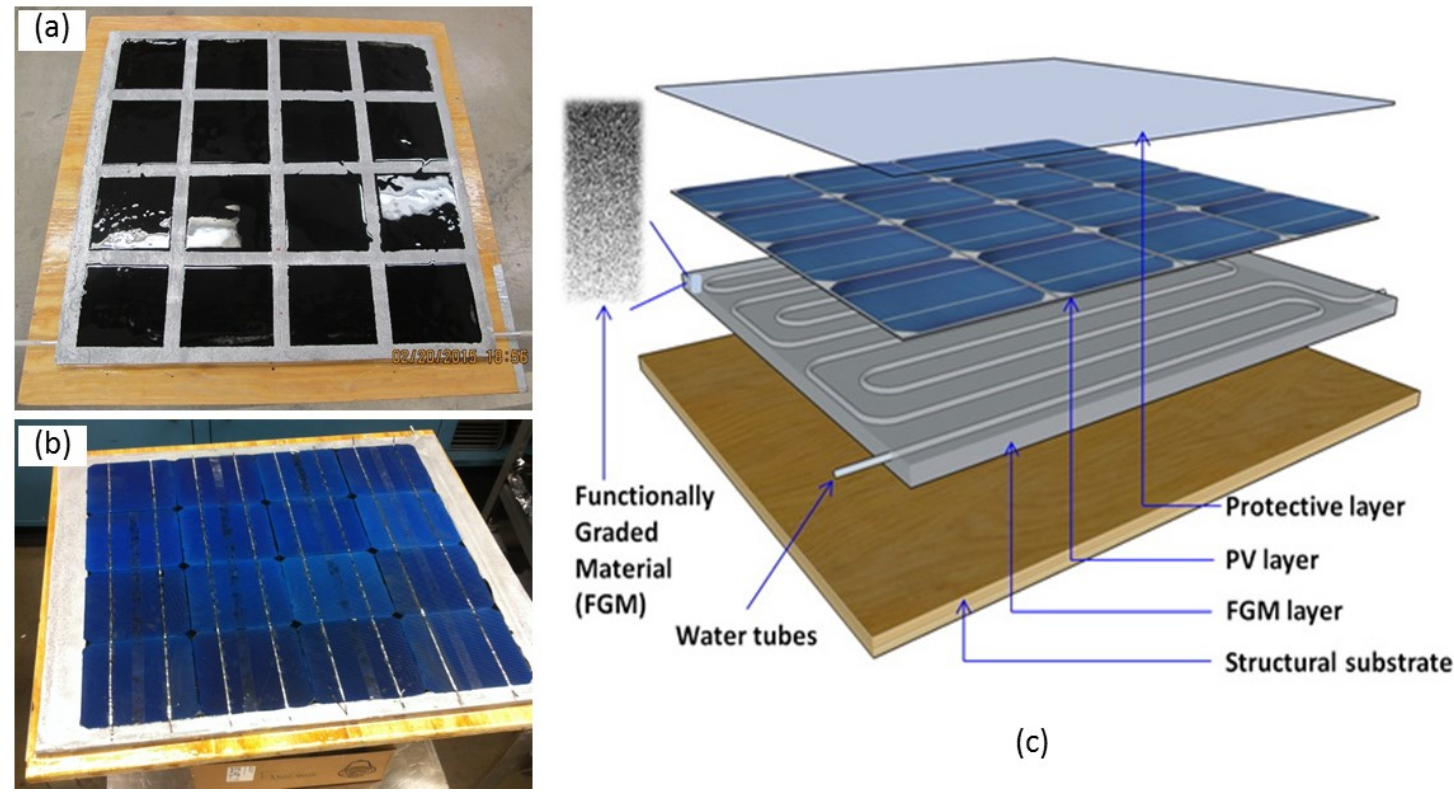

(c)

Figure 3. A novel building-integrated photovoltaic-thermal (BIPVT) roofing panel: (a) layering of conductive adhesive; (b) integrated solar panel, and; (c) the BIPVT layers for assembly.

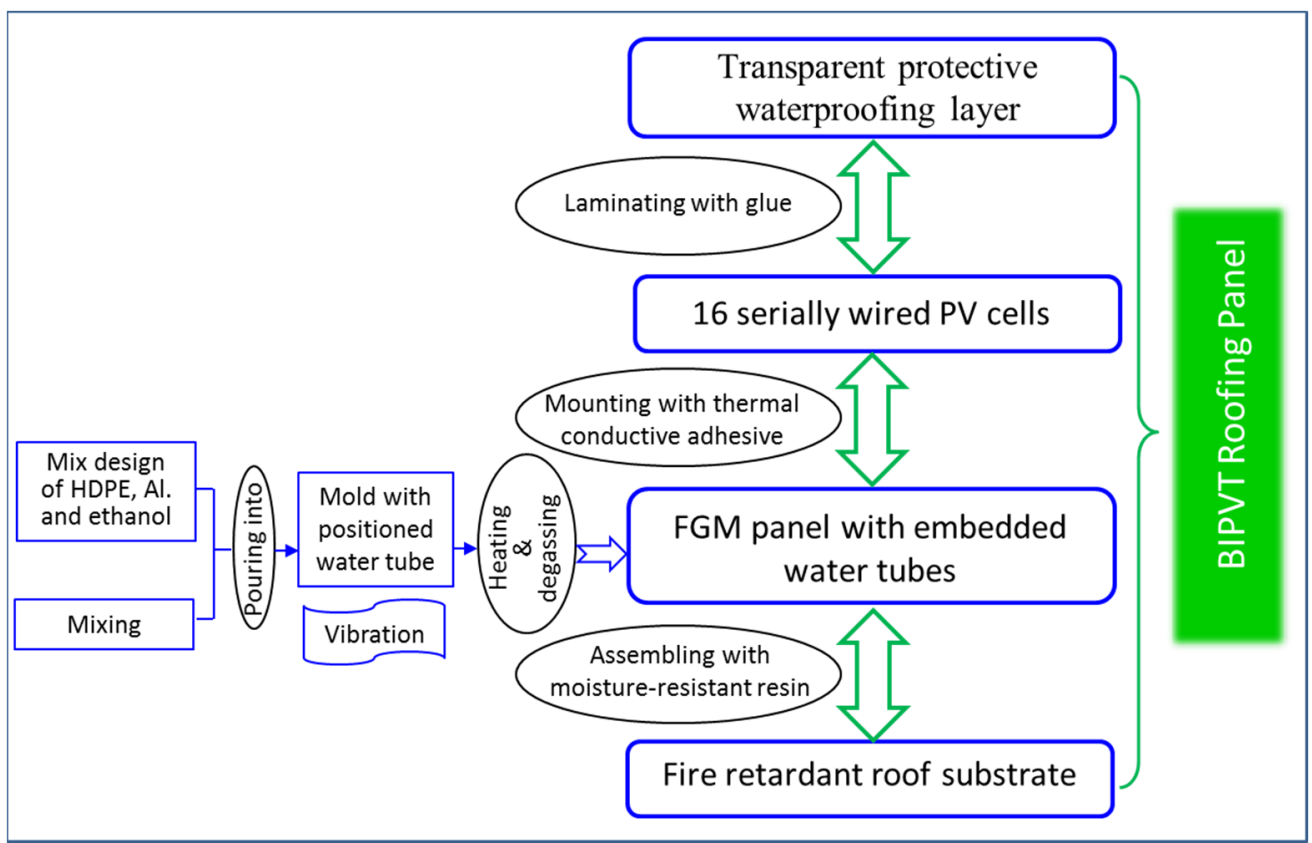

Figure 4 Illustration of the fabrication procedures of the BIPVT panel.

\subsection{Integration of a multifunctional roofing system}

A multifunctional roofing system can be easily assembled by using the proposed BIPVT panel, which is sized to be easily integrated with the industry standard structural framing spacing of 304.8 $\mathrm{mm}$ on center as shown in Figure 5. Custom panels can also be easily developed for longer spans. The length of the panel can be either $1219 \mathrm{~mm}$ or $2438 \mathrm{~mm}$, based on the weight and thickness 
requirements (1219mm is illustrated for demonstration). The prototype design references the International Building Code (IBC 2015) [46] for the roof assembly requirements for weather protection, such as flashings to prevent moisture penetrations at all roof interruptions and terminations. The proposed panelized system will employ a field-applied joint system while gasketed design alternatives can also be developed. Both electrical and fluid connections will be made between the individual panels. The following major components are included in the design.

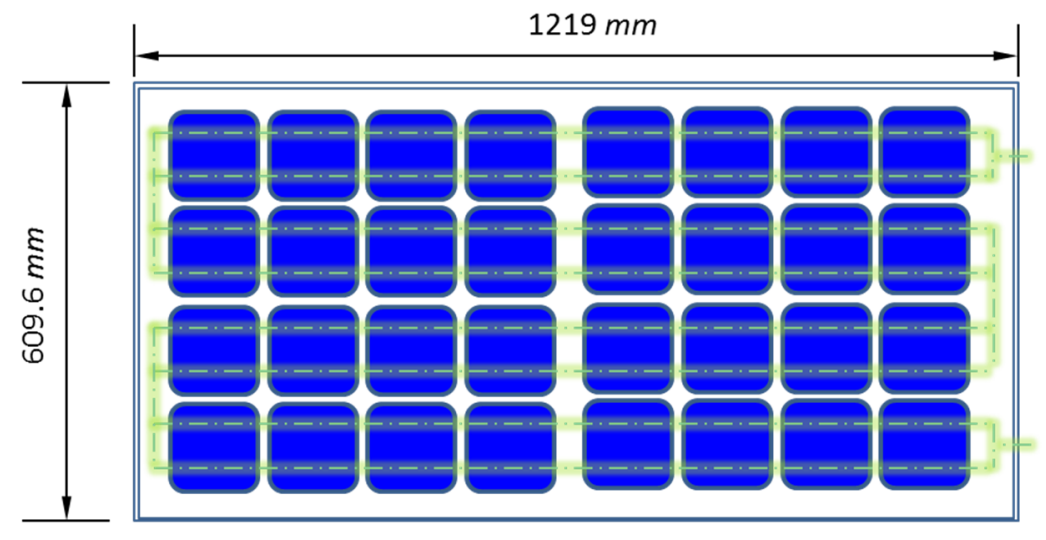

Figure 5 Connection of the BIPVT roofing panel

- All PV series array circuiting will be National Electric Code (NEC) compliant.

- The FGM layer (Task I) provides the polymer matrix for the closed water loop heat exchange system. Heat energy will be captured in the FGM layer and gathered utilizing an insulated piping in the attic space.

- The structural substrate provides the structural support for the BIPVT panel so it can function as a roof deck and structural diaphragm for the building.

Additionally there is a transparent protective layer above the PV layer which functions as a waterproof membrane. A glass superstrate can be used in the current design. Our future exploration of the superstrate design will include the evaluation of alternative polymer superstrates which are attractive due to their low weight. The manufacture of this panel will not be more complex than the existing combination of a traditional roof and PV panels. The proposed BIPVT panel can be integrated into a building's skin with relevant system components such as water circulation, flow control and heat storage. The innovations of the proposed BIPVT technology are summarized as follows:

- Due to the ability to control temperatures through the water flow, the PV modules can work at lower temperatures in the summer and thus stably obtain a higher efficiency for PV utilization.

- The collected hot water can be directly utilized by water heating systems for indoor or external heat supply.

- Due to the temperature control on the roof, better thermal comfort in the building can be achieved in the summer time, a cooler room temperature can be obtained, and the energy demand for cooling can be reduced.

- In winter, a warm water flow can be used to remove frost or ice on the roof, clean solar panels, and thus restore and enhance solar energy utilization. 
Notes that traditional solar panels are rebuilt on the rooftop or attached to structural elements of the building skin, which is less than optimal. Firstly, the power generating elements of such panels are typically adhered to a structural substrate, supported by a structural framework that penetrates the building's water proofing system. Secondly, traditional solar panels cannot shield the building skin from wind loads and conventional configurations necessitate redundancies as the panel substrate and frame must be designed to resist the same wind and snow loads as the building envelope. However, the proposed BIPVT technology is not a simple superposition of individual structural component and PV module, but provides a viable solution to significantly increase overall energy utilization efficiency while alleviating the disadvantages of a single approach. It enables heat harvesting while improving the PV utilization efficiency by controlling the temperature of PV modules. This holistic design meets multifunctional purposes, including insulation of thermal; structural integrity under wind, rain, snow, or hail loading; mechanical strength for temperature and moisture induced stresses; and also its aesthetical appearance.

\section{Modeling procedures and performance evaluation of the multifunctional BIPVT panel}

The performance of the prototype BIPVT panel in terms of its thermal efficiency via warm water collection and electric efficiency via electricity generation by the PV cells are investigated in this section. The modeling procedures of the thermal and electric efficiencies are presented in detail in subsections 3.2 and 3.3, respectively. The overall efficiency of the present BIPVT panel and comparisons with other relevant PVT collectors is provided in subsection 3.4.

\subsection{Laboratory testing setup}

The performance of the prototype BIPVT panel was investigated at the Carleton Laboratory by using the solar simulator from Atlas Material Testing Solutions, Germany (http://atlas$\mathrm{mts.com} /$ services/solar-testing-services/solarconstant-system/). The solar simulator is established in a purpose-built room with a temperature-controlled exhaust system, which cools the room by forced-air ventilation as shown in Figure 6 (a). A special metal-halide MHG lamp is assembled in the solar simulator, which can provide an irradiance up to $4 \mathrm{~kW} / \mathrm{m}^{2}$. The solar simulator is able to (1) offer high irradiance efficiency and superior spatial uniformity on the test area; (2) produce a dense multiline spectrum of the rare earths that is comparable to a continuous spectrum; and (3) provide a spectral distribution very close to natural sunlight (total radiation as defined by CIE 85) combined with the MHG lamp and optical filters. The lamp was mounted to modular tracks located on the ceiling of the chamber. The lamp can be moved and rotated to suit specific testing needs. During the test, the BIPVT panel was located under the solar lamp with a fixed distance of $1422.4 \mathrm{~mm}$ from the top surface of the panel to the bottom edge of the lamp. The irradiance intensity of the metal lamp was controlled by adjusting the power output from the simulator controller (Figure 6.(b)). The adjustable scale of the simulator ranges from 51 to 92 with an interval of 1 , which corresponds to an irradiance intensity scope from $620 \mathrm{~W} / \mathrm{m}^{2}$ to $1250 \mathrm{~W} / \mathrm{m}^{2}$ with the selected height. A water source was connected to the inlet of the panel through a polyvinyl chloride (PVC) pipe with a diameter of $7.62 \mathrm{~mm}$. Water flow was established using a pump to cool down the surface temperature of the FGM panel as well as the solar cell. A laboratory flow-meter (Figure 6.(b)) with a flow range of $2-250 \mathrm{ml} / \mathrm{min}$ and accuracy of $2 \%$ was used to control the flowrate inside the water tube. 

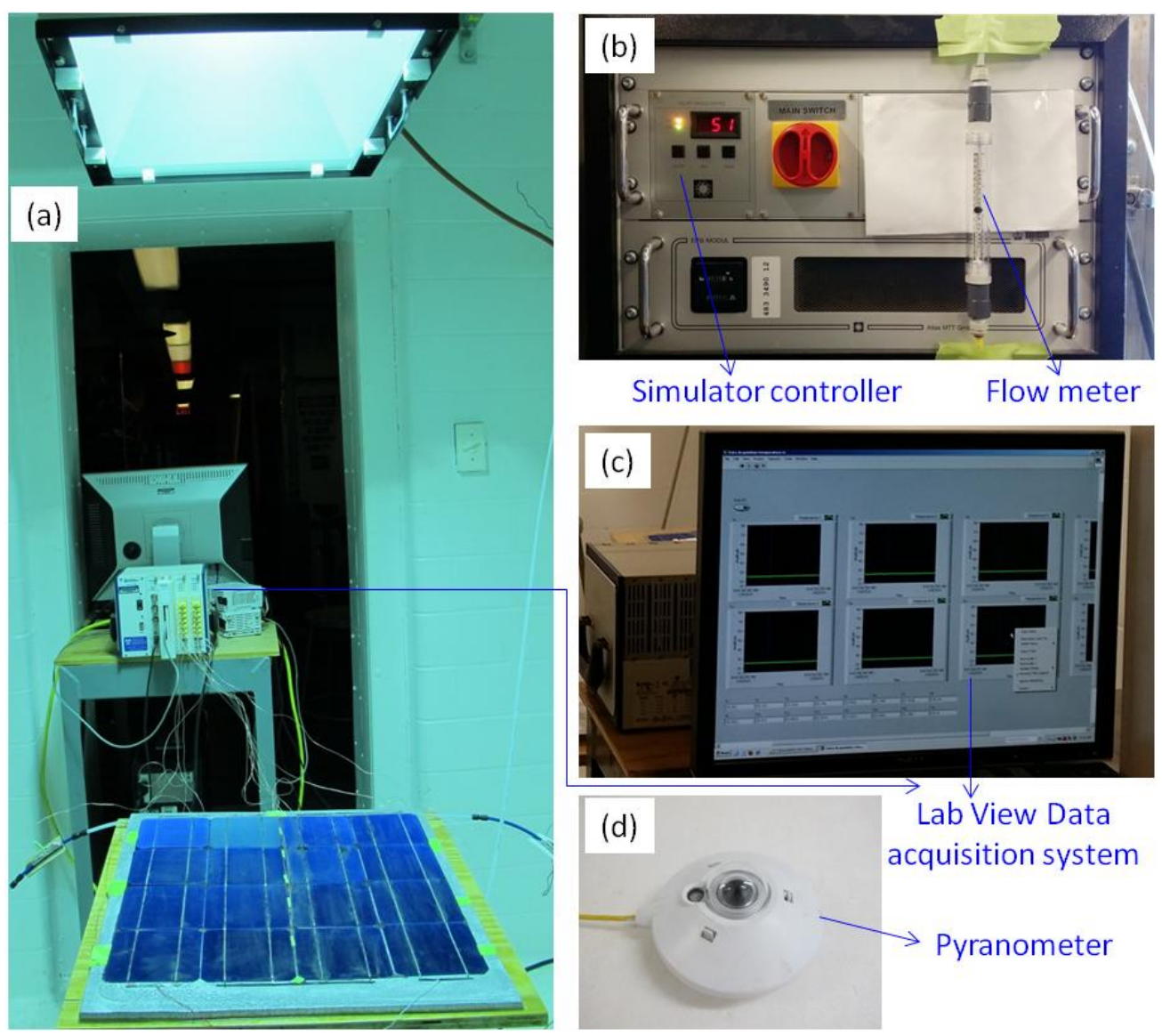

Figure 6 Performance evaluation of the BIPVT Panel: (a) test setup; (b) simulator controller and flow meter; (c) data acquisition system; and (d) Pyranometer.

Fourteen thermocouples were installed to examine the temperature distribution throughout the whole panel surface. Among those fourteen thermocouples, twelve (6 located at the two edges of the panel and other 6 were distributed at the center line on the solar panel) were attached on the FGM panel; while two were attached on the inlet (No. 1) and outlet (No. 15) aluminum water tubes. The detailed distributions of the thermocouples were shown in Figure 7. The temperature readings from the thermocouples were acquired by the data acquisition system with a sampling frequency of $2 \mathrm{~Hz}$. 


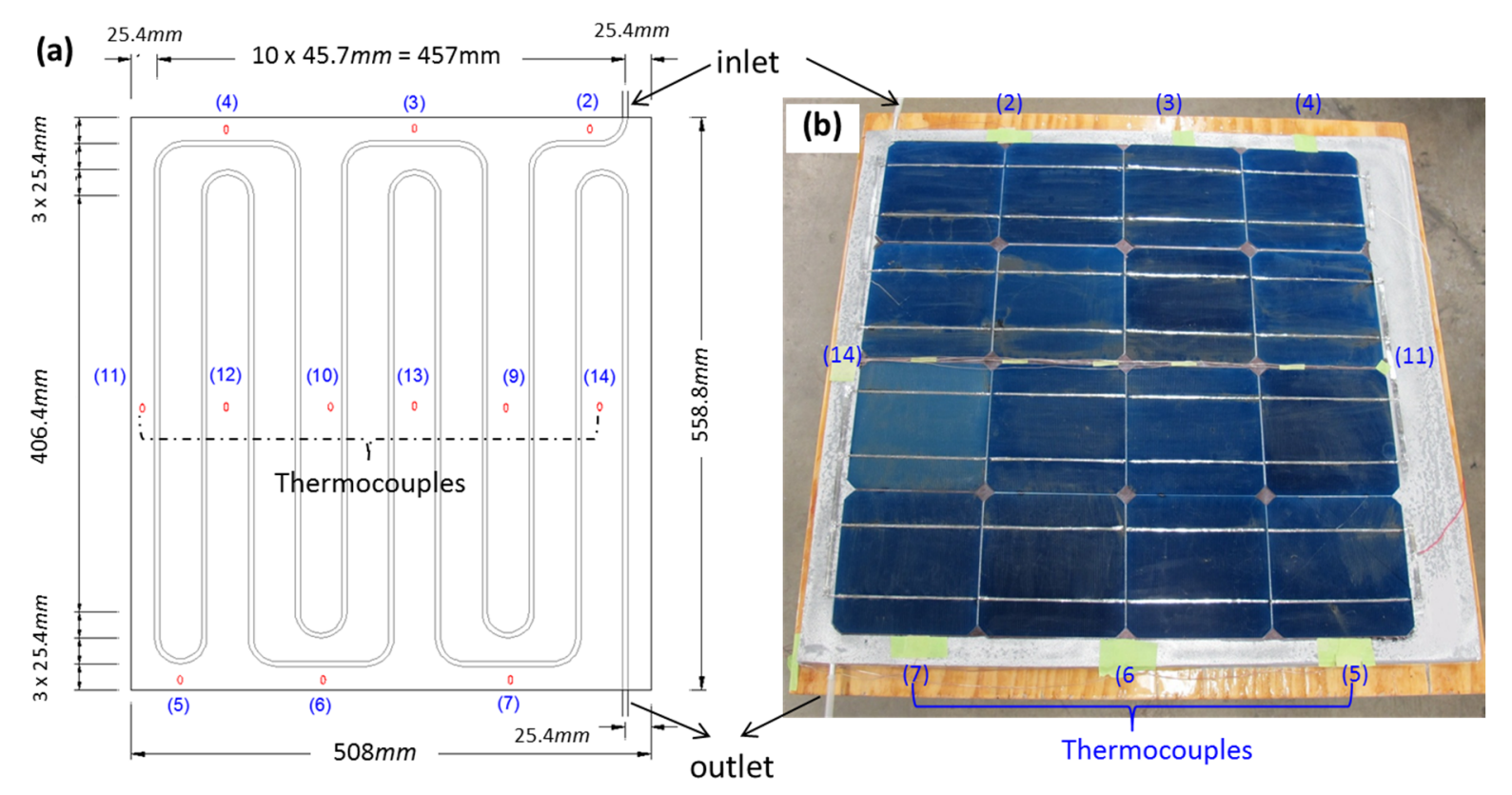

Figure 7 Thermal couple distributions: (a) schematic illustration; and (b) real BIPVT panel

\subsection{Estimation of heat collection}

The test consists of two stages. In the first stage, the BIPVT panel was exposed to solar radiation without water flowing inside until a stable state was reached; while in the second stage, a stable water flow was introduced and controlled by the flow meter until another stable state was reached. The thermal distributions of the FGM panel under different irradiance levels $(620,800$ and $\left.1000 \mathrm{~W} / \mathrm{m}^{2}\right)$ at different water flows $\left(30,60,90\right.$ and $120 \mathrm{ml} / \mathrm{min}$ for $620 \mathrm{~W} / \mathrm{m}^{2}$; and 30, 60, 90 and $150 \mathrm{ml} / \mathrm{min}$ for 800 and $1000 \mathrm{~W} / \mathrm{m}^{2}$ ) were monitored. It was found that the temperature evolution trends for different flow rates under different irradiance levels are quite similar. For this reason, only two typical ones corresponding to an irradiance level of $620 \mathrm{~W} / \mathrm{m}^{2}$ are shown in Figure 8. T1 and T15 are the measured temperatures of the water in the inlet and outlet tubes, respectively, which are static in the first stage. It shows that the temperature of the BIPVT panel gradually increases in the first stage as continuous irradiance energy is absorbed and accumulates in the panel. Under the selected irradiance level $\left(620 \mathrm{~W} / \mathrm{m}^{2}\right)$, it takes about 2.5 hours for the BIPVT panel to reach a relatively stable peak temperature. As shown in Figure 8, the temperature of the BIPVT panel during this stage increases from room temperature $\left(\sim 25^{\circ} \mathrm{C}\right)$ to a peak value $\left(\sim 51.5^{\circ} \mathrm{C}\right)$. It was also observed that the peak temperatures at the two edges are lower than those at the central line of the panel. Since the water circuit was closed in this stage, the temperature of both the inlet and outlet water initially increased and then reached to a stable state in a much shorter period of time compared with those on the surface of the BIPVT panel. When the temperature of the panel reaches a stable peak value, the water valve was turned on and a stable flow of water was introduced and controlled by the flow meter, which initiates the second stage. 

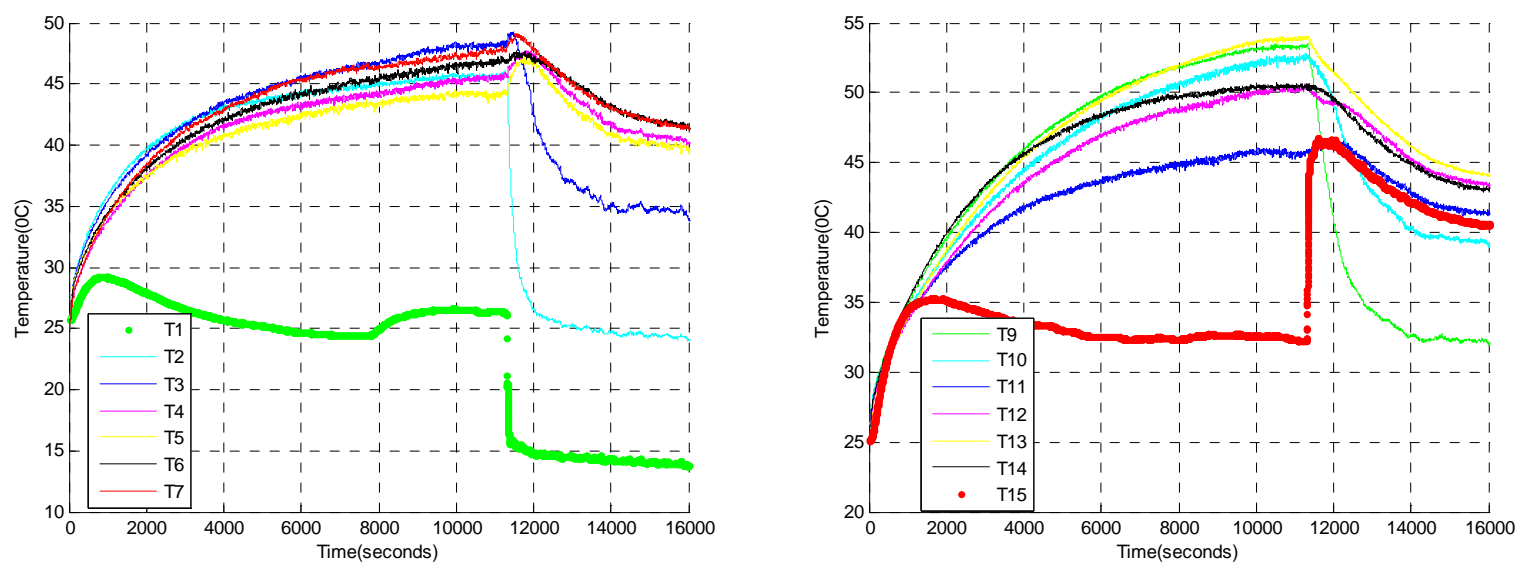

(a) Water flow $=30 \mathrm{ml} / \mathrm{min}$
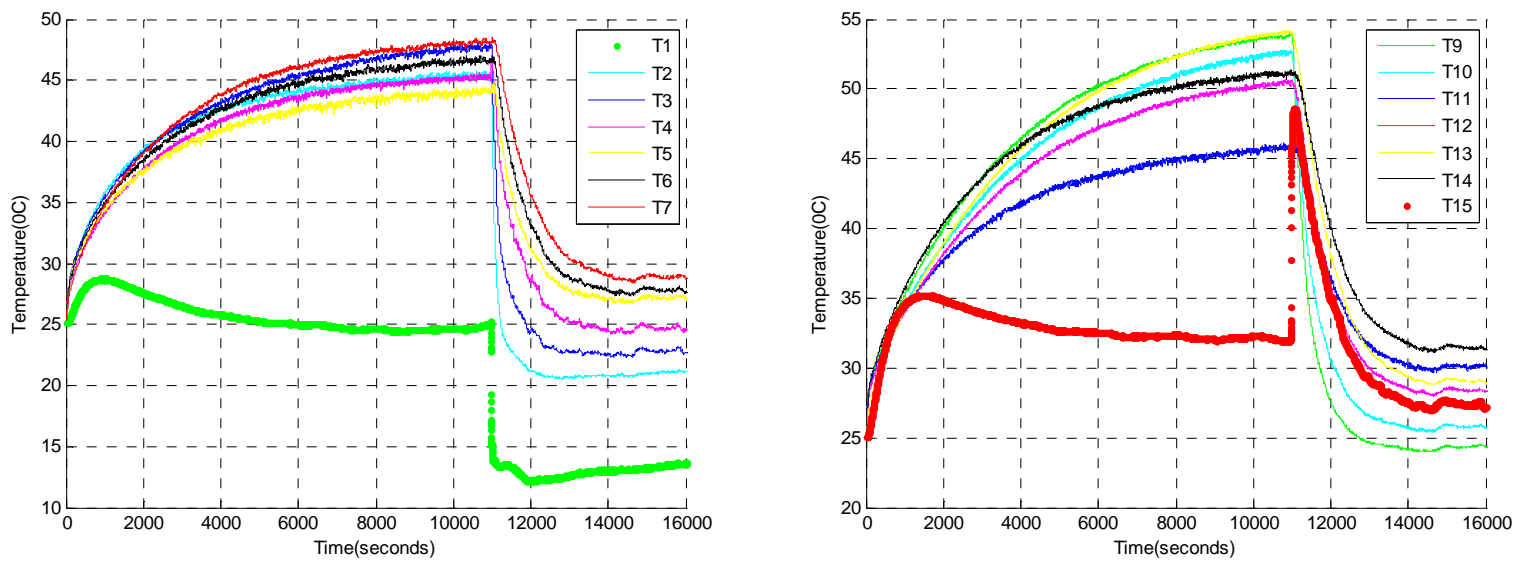

(b) Water flow $=120 \mathrm{ml} / \mathrm{min}$

Figure 8 Thermal distribution of the BIPVT panel at an irradiance level $=620 \mathrm{~W} / \mathrm{m}^{2}$

In the second stage, the recorded surface temperatures of the BIPVT panel rapidly drop due to the water flowing through the tubes embedded in the FGM panel, until another stable state is reached. Once the water flow is introduced, the temperature on the inlet water tube $\left(T_{1}\right)$ suddenly drops as cool water source flows into the circuit; while on the other hand, the temperature on the outlet water tube $\left(T_{15}\right)$ suddenly increases as heated water fluxes out from the outlet water tube. Thereafter, the outlet water temperature gradually decreases as the water continues flowing in the circuit until it reaches to the second stable state. The time for the temperature on the panel surface to stabilize drops from the first stable state to the second one, and consequently the temperature at the second stable state, varies from the introduced water flowrate. Figure 8 shows that the lower the water flowrate is, the longer the time that is required to cool down the BIPVT panel and the higher the temperature is at the second stable state. Similar to the first stage, the temperate at the edge parts is lower than that in the central line of the panel because the solar irradiance is more direct in the central line than it is at the edges.

The thermal distributions of the BIPVT panel at other irradiance levels $\left(800\right.$ and $\left.1000 \mathrm{~W} / \mathrm{m}^{2}\right)$ with different water flowrates are similar with those shown in Figure 8. Table 1 summarizes the temperature increase of the outlet water compared with the inlet water $\left(\Delta T_{\text {water }}\right.$, which is the temperature difference between the outlet water $\left(T_{15}\right)$ and that of the inlet water $\left(T_{1}\right)$ in the second 
stable stage and indicates the harvested heat energy collected by the warm water) and the temperature decrease of the BIPVT surface $\left(\Delta T_{\text {panel }}\right.$, which is the average temperature difference of all thermocouples attached on the BIPVT panel surface between the first and second stages and reflects the enhanced electricity generation efficiency of the solar cell). It shows from Table 1 that the increase in temperature of the collected water from the BIPVT panel can be as high as $37.5^{\circ} \mathrm{C}$ at an irradiance of $1000 \mathrm{~W} / \mathrm{m}^{2}$ with a relatively low flow rate of $30 \mathrm{ml} / \mathrm{min}$, and that the decreased surface temperature of the BIPVT can be as high as $32{ }^{\circ} \mathrm{C}$ when the flowrate increases to 150 $\mathrm{ml} / \mathrm{min}$. It is expected that, as the water flowrate increases, the BIPVT panel surface temperature will further decrease.

To quantify the thermal performance, the collected heat gain by the present BIPVT panel and its corresponding thermal conversion efficiency will be evaluated. According to Ibrahim et al. [35], the useful collected heat gained by a flat plate PVT collector can be defined either as (1) the coupling results of average mass flow rate, heat capacity of the temperature lowering medium and the temperature difference at the collector inlet and outlet, or (2) the difference between the absorber solar radiation and thermal heat losses which can be identified by the well-known HotttelWhillier equation [47]. The first method is simple and straightforward as it is directly calculated from instantaneous measurements within a certain period of time in laboratory or field test, and thus is suitable for stable measurement from well-controlled laboratory testing or in-field measurement made on clear days. Therefore, the thermal efficiency obtained by this method is usually termed as instantaneous thermal efficiency, which is considered valid only if the weather data are representative of long-term performance [48]. However, because of many uncertainties such as occasional cloudiness, varying angle of incidence of sun days, varying ambient temperatures, and varying surrounding wind speed, and etc., this method is not able to provide the long-term true performance.

Though the Hottel-Whillier model is able to provide better estimation of the long-term performance of a PVT collector in a sense of statistical average, it involves many operating parameters of a PVT product, such as the emittance of the panel, wind heat transfer coefficient, sky temperature, convection heat transfer coefficients, and natural convection loss [27,29]. Those parameters need to be statistically determined from massive field tests. At current stage, they are not available for this prototype BIPVT roofing panel. Thus the first method is applied in this study to calculate the thermal efficiency of the present BIPVT roofing panel. The performance of longterm efficiency of the present BIPVT will be evaluated in our future study by following the HottelWhillier model when more detailed parameters of the final product of the BIPVT such as emittance of the panel after protective layer above the PV layer is applied, overall convection heat transfer coefficient, and operating climate parameters during data collection period.

According to the definition of instantaneous thermal efficiency [35], the useful collected heat $Q_{\text {water }}$ gain by the BIPVT panel at different water flowing rates can be calculated by Eq. (1):

$$
Q_{\text {water }}=\dot{m}_{\text {water }} \times C_{\text {water }} \times \Delta T_{\text {water }}
$$

where $\dot{m}_{\text {water }}$ is the mass flow rate of the water flowing in the water pipe and $C_{w a t e r}=$ $4.19\left(\mathrm{~kJ} / \mathrm{kg} \cdot{ }^{\circ} \mathrm{F}\right)$ is the specific heat capacity of water.

The thermal efficiency of the BIPVT panel $\eta_{\text {thermal }}$ is a ratio of the collected thermal energy to the irradiance energy absorbed by the panel, which can be expressed as $[27,38]$ :

$$
\eta_{\text {thermal }}=\frac{Q_{\text {water }}}{E_{I N}}=\frac{Q_{\text {water }}}{I_{R} \cdot A}
$$


where $E_{I N}=I_{R} \cdot A$ is the absorbed irradiance by the BIPVT panel, which is the product of the irradiance intensity $\left(I_{R}\right)$ and the total area of the BIPVT panel and the frame. A $=0.28 \mathrm{~m}^{2}(508 \mathrm{~mm}$ $\times 558.8 \mathrm{~mm}$ ) for the prototype BIPVT panel in this study. It should be mentioned that the thermal efficiency defined in Eq. (2) does not take into account of the energy required to pump the water into the panel, this required energy is also not accounted for in the definition of the electric efficiency, which will be provided in Eq. (4) in subsection 3.3.

Table 1 Overall thermal performance of the BIPVT

\begin{tabular}{|c|c|c|c|c|c|}
\hline $\begin{array}{c}\text { Solar radiation } \\
\left(\mathrm{W} / \mathrm{m}^{2}\right)\end{array}$ & $\begin{array}{c}\text { Water flow rate } \\
(\mathrm{ml} / \mathrm{min})\end{array}$ & $\begin{array}{c}\Delta \boldsymbol{T}_{\text {water }} \\
\left({ }^{\circ} \mathrm{C}\right)\end{array}$ & $\begin{array}{c}\Delta \boldsymbol{T}_{\text {panel }} \\
\left({ }^{\circ} \mathrm{C}\right)\end{array}$ & $\begin{array}{c}\boldsymbol{Q}_{\text {water }} \\
(\mathrm{W})\end{array}$ & $\begin{array}{c}\boldsymbol{\eta}_{\text {thermal }} \\
(\%)\end{array}$ \\
\hline \multirow{4}{*}{$\mathbf{6 2 0}$} & 30 & 26.5 & -12.7 & 55.52 & 31.54 \\
\cline { 2 - 6 } & 60 & 22.94 & -18.6 & 93.86 & 53.33 \\
\cline { 2 - 6 } & 90 & 17.6 & -21.8 & 110.62 & 62.85 \\
\hline \multirow{4}{*}{$\mathbf{8 0 0}$} & 120 & 14.1 & -23.9 & 119.83 & 67.14 \\
\cline { 2 - 6 } & 30 & 32.2 & -15.7 & 67.46 & 29.71 \\
\cline { 2 - 6 } & 60 & 25.6 & -20.8 & 107.26 & 47.23 \\
\cline { 2 - 6 } & 90 & 20.3 & -24.2 & 127.59 & 56.18 \\
\hline \multirow{4}{*}{$\mathbf{1 0 0 0}$} & 150 & 13.6 & -28.1 & 142.46 & 62.73 \\
\hline & 30 & 37.5 & -14.3 & 78.56 & 27.68 \\
\cline { 2 - 6 } & 60 & 29.5 & -22.9 & 123.61 & 43.54 \\
\cline { 2 - 6 } & 90 & 23.7 & -27.8 & 148.95 & 52.47 \\
\hline & 150 & 16.1 & -32 & 168.65 & 59.41 \\
\hline
\end{tabular}

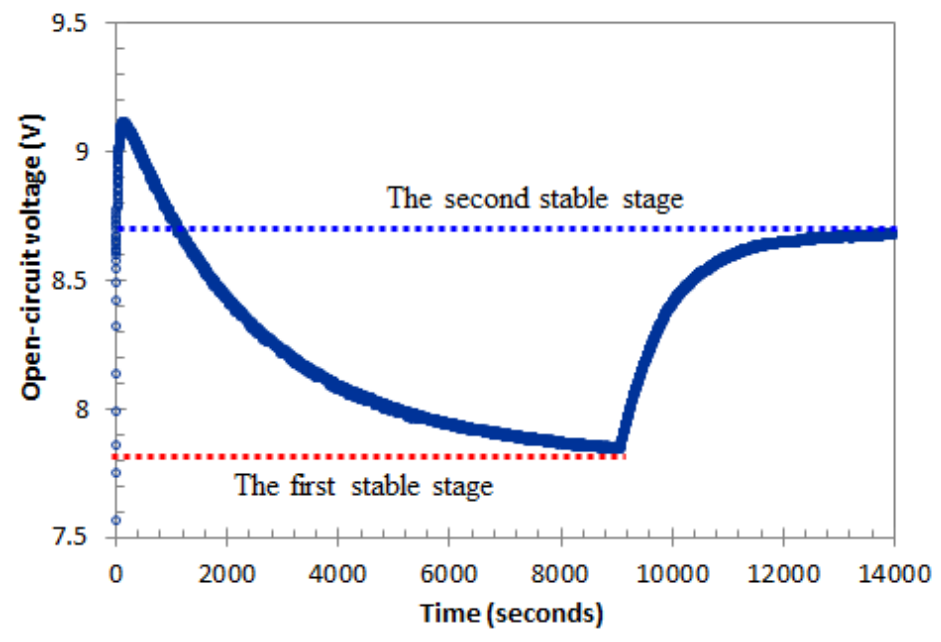

Figure 9 Open-circuit voltage from the BIPVT.

\subsection{Estimation of electricity generation}

The generated voltages of the BIPVT panel under different solar irradiances with different introduced water flow were collected by the LabVIEW data acquisition system 
(http://www.ni.com/labview/). The variance of a typical open-circuit voltage is shown in Figure 9. In the initial few seconds just right after the solar simulator was turned on, the voltage rapidly increased until a peak value was reached, which is the stable stage of the metal lamp. As the solar simulator is kept on, a certain amount of the irradiance energy is converted to heat energy and the temperature of the solar cells gradually increases. It shows from Figure 9 that the output voltage gradually decreases as the solar cell temperature increases until it reaches the first stable stage as described in subsection 3.2.

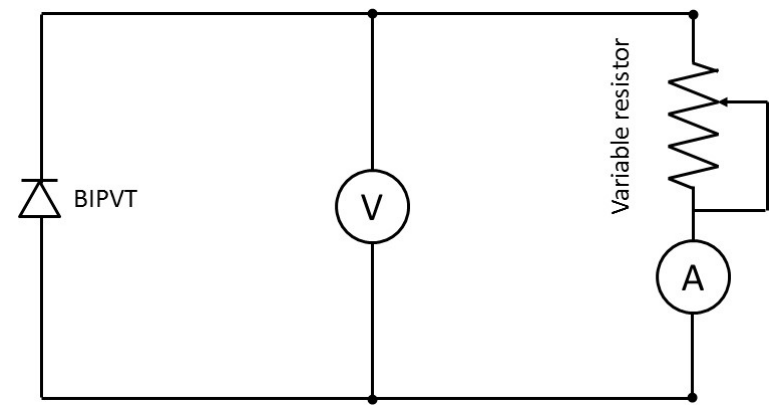

Figure 10 Circuit diagram for the I-V characteristics determination.
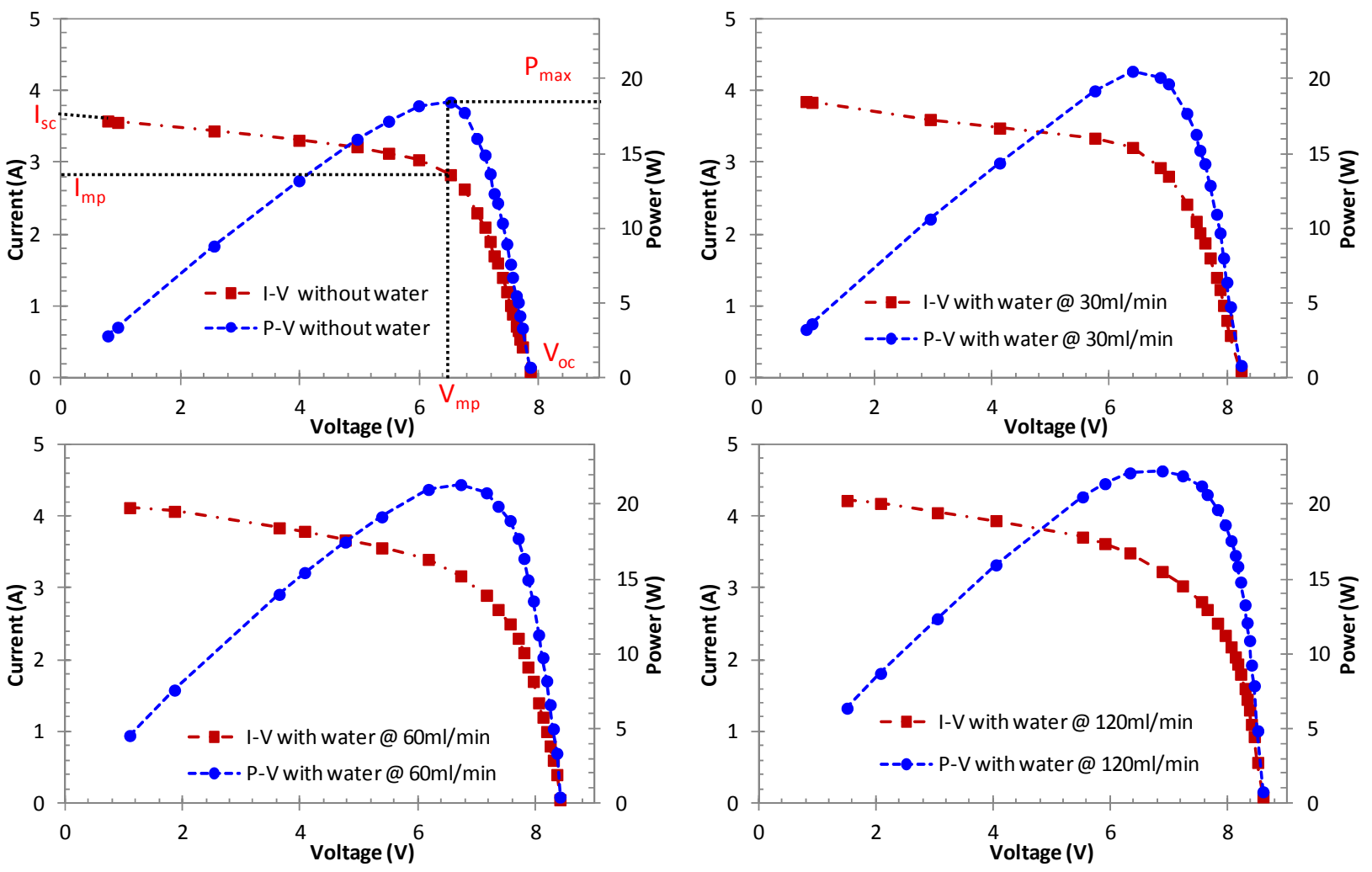

Figure $11 \mathrm{I}-\mathrm{V}$ curve and output power of the BIPVT with different flowing water under irradiance of $620 \mathrm{~W} / \mathrm{m}^{2}$ : (a) without water; (b) water flowing rate $=30 \mathrm{ml} / \mathrm{min}$; (c) water flowing rate $=60 \mathrm{ml} / \mathrm{min}$; and (d) water flowing rate $=120 \mathrm{ml} / \mathrm{min}$.

Once the water flow was introduced, the temperature of both the FGM panel and solar cells rapidly drop. As a consequence, the output voltage considerably increases until the second temperature stable stage was reached, which is shown in Figure 9. During this whole process, it is 
obvious that the electricity conversion efficiency of the BIPVT panel drops to its minimum at the first stable stage (lowest voltage at its maximum temperature) and reaches to its maximum at the second stable stage (highest voltage at its minimum temperature). With the introduced water flowing, the open-circuit voltage at the second stable stage is about $11 \%$ higher than that at the first stable stage without water introduced.

In order to quantify the enhanced efficiency electricity generation of the BIPVT, a circuit shown in Figure 10 was set up with the LabVIEW data acquisition system to measure the generated electricity by the solar cells. A heavy-duty adjustable resistor was included in the circuit. In obtaining the current-voltage (I-V) curve of the solar panel, by adjusting the resistance, the current in the circuit was measured by a digital multimeter. The current reaches its maximum (ISC) in a short-circuit when the resistance is zero, while the voltage reaches its maximum $\left(V_{O C}\right)$ in an opencircuit where the resistance can be considered as infinite through which no current flows. By setting different values of resistance in between, the I-V curve can be traced and the panel can be characterized at different irradiance intensities with different water flowing rates.

The electrical power produced by the cell can be easily determined along the I-V sweep by the equation $P=I V$. The corresponding I-V and power-voltage $(\mathrm{P}-\mathrm{V})$ curves for the BIPVT panel at an irradiance of $620 \mathrm{~W} / \mathrm{m}^{2}$ with different water flowrates are shown in Figure 11. At the $I_{S C}$ and $V_{O C}$ points, the output powers are zero, while the maximum power can be easily identified at the peak point from the $\mathrm{P}-\mathrm{V}$ curve. At the maximum power point the voltage and current are denoted as $V_{M P}$ and IMP respectively, which is illustrated in Figure 11(a).

From the I-V and P-V curves, some basic parameters such as fill factor (FF) and electricity conversion efficiency $\left(\eta_{p v}\right)$ can be determined for the BIPVT under different irradiances with different water flowrates by following some fundamental studies in the literature [49,50]. The Fill Factor (FF) is essentially an index of the BIPVT panel quality. It is calculated in Eq. (3) by comparing the maximum output electricity $\left(E_{M A X}\right)$ to the theoretically calculated vale $\left(E_{T}\right)$ that would be generated at both the open circuit voltage and short circuit current together. A larger fill factor is desirable, which corresponds to an I-V sweep that is more square-like.

$$
F F=\frac{E_{M A X}}{E_{T}}=\frac{I_{M P P} \cdot V_{M P P}}{I_{S C} \cdot V_{O C}}
$$

The electricity conversion efficiency $\left(\eta_{p v}\right)$ is defined as the ratio of the output electricity $E_{p v}$ with respect to the absorbed solar irradiance $E_{I N}$ by the BIPVT panel, which is represented in Eq. (4). $E_{p v}$ can be taken as $E_{M A X}$ since the solar cell can be operated up to its maximum energy output to get the maximum efficiency. In determining the efficiency, the dimensions of the BIPVT frames were also considered in the calculations as they are necessary components that take up area though they are there for structural purposes.

$$
\eta_{p v}=\frac{E_{p v}}{E_{I N}}=\frac{E_{M A X}}{I_{R} A}
$$

Table 2 Electric performance of the BIPVT

\begin{tabular}{|c|c|c|c|c|c|c|c|c|}
\hline $\begin{array}{c}\text { Solar } \\
\text { irradiance } \\
\left(\mathrm{W} / \mathrm{m}^{2}\right)\end{array}$ & $\begin{array}{c}\text { Water } \\
\text { flow rate } \\
(\mathrm{ml} / \mathrm{min})\end{array}$ & $\begin{array}{c}\mathrm{ISC} \\
(\mathrm{ADC})\end{array}$ & $\begin{array}{c}\text { VoC } \\
(\mathrm{VDC})\end{array}$ & $\begin{array}{c}\mathrm{I}_{\mathrm{MP}} \\
(\mathrm{ADC})\end{array}$ & $\begin{array}{c}\mathrm{V}_{\mathrm{MP}} \\
(\mathrm{VDC})\end{array}$ & $\begin{array}{c}\boldsymbol{E}_{\boldsymbol{p} \boldsymbol{v}} \\
(W)\end{array}$ & $\begin{array}{c}F F \\
(\%)\end{array}$ & $\begin{array}{c}\boldsymbol{\eta}_{\boldsymbol{p} \boldsymbol{v}} \\
(\%)\end{array}$ \\
\hline \multirow{3}{*}{620} & 0 & 3.69 & 7.86 & 2.83 & 6.52 & 18.45 & 63.62 & 10.48 \\
\cline { 2 - 10 } & 30 & 3.92 & 8.23 & 3.21 & 6.39 & 20.51 & 63.58 & 11.65 \\
\cline { 2 - 9 } & 60 & 4.17 & 8.41 & 3.17 & 6.73 & 21.32 & 60.83 & 12.11 \\
\hline
\end{tabular}




\begin{tabular}{|c|c|c|c|c|c|c|c|c|}
\hline \multirow{5}{*}{} & 90 & 4.2 & 8.54 & 3.19 & 6.88 & 21.96 & 61.19 & 12.48 \\
\cline { 2 - 9 } & 120 & 4.24 & 8.6 & 3.29 & 6.89 & 22.65 & 62.11 & 12.87 \\
\hline \multirow{5}{*}{800} & 0 & 4.69 & 9.28 & 3.64 & 7.47 & 27.21 & 62.51 & 11.98 \\
\cline { 2 - 9 } & 30 & 5.09 & 9.47 & 3.98 & 7.62 & 30.35 & 62.96 & 13.36 \\
\cline { 2 - 9 } & 60 & 5.27 & 9.56 & 4.09 & 7.67 & 31.37 & 62.27 & 13.81 \\
\cline { 2 - 9 } & 90 & 5.31 & 9.57 & 4.13 & 7.72 & 31.88 & 62.74 & 14.04 \\
\hline \multirow{5}{*}{1000} & 150 & 5.39 & 9.71 & 4.22 & 7.81 & 32.96 & 62.97 & 14.51 \\
\hline & 0 & 5.68 & 10.02 & 4.52 & 8.01 & 36.22 & 63.61 & 12.76 \\
\cline { 2 - 9 } & 30 & 6.17 & 10.31 & 4.91 & 8.24 & 40.46 & 63.60 & 14.25 \\
\cline { 2 - 9 } & 60 & 6.26 & 10.42 & 5.09 & 8.32 & 42.35 & 64.92 & 14.92 \\
\cline { 2 - 9 } & 90 & 6.38 & 10.57 & 5.18 & 8.43 & 43.67 & 64.75 & 15.38 \\
\hline & 150 & 6.62 & 10.83 & 5.24 & 8.57 & 44.91 & 62.64 & 15.82 \\
\hline
\end{tabular}

The determined parameters of the BIPVT panel under different irradiances with different water flowrates are summarized in Table 2. Overall, the output electricity $E_{p v}$ increases as the solar radiation increases, and the short circuit current $I_{S C}$, open circuit voltage $V_{O C}$, max power current $I_{M P}$ and max power voltage $V_{M P}$ increase with an increase in the introduced water flowrates, which are due to the gradually decreased operation temperature of the BIPVT panel. Under a solar irradiance of $620 \mathrm{~W} / \mathrm{m}^{2}$, compared with the case that no water flow is introduced, the output electricity energy increases from $18.45 \mathrm{~W}$ to $22.65 \mathrm{~W}$ and the electric efficiency raises from $10.5 \%$ to $12.9 \%$ after a water flow of $120 \mathrm{ml} / \mathrm{min}$ is introduced. Both $E_{p v}$ and $\eta_{p v}$ increase as the solar irradiance and water flowrates are increased. With a water flowrate of $150 \mathrm{ml} / \mathrm{min}, E_{p v}$ reaches $32.96 \mathrm{~W}$ and $44.91 \mathrm{~W}$ and $\eta_{p v}$ reaches $14.51 \%$ and $15.82 \%$ under solar irradiances of 800 and $1000 \mathrm{~W} / \mathrm{m}^{2}$, respectively. The PV efficiency is enhanced by $21.1 \%$ and $24.0 \%$ for those two solar irradiances respectively, comparing with the case in which no water flow is introduced. Based on the thermal and electric performances provided in Tables 1 and 2, the total energy efficiencies $\eta_{T}=\eta_{\text {thermal }}+\eta_{p v}$ of the BIPVT panel under different solar irradiances and water flowing rates can be estimated. The maximum $\eta_{T}$ evaluated in this study under the solar irradiance of $620 \mathrm{~W} / \mathrm{m}^{2}$ with water flowing rate of $120 \mathrm{ml} / \mathrm{min}, 800 \mathrm{~W} / \mathrm{m}^{2}$ with water rate of 150 $\mathrm{ml} / \mathrm{min}$, and $1000 \mathrm{~W} / \mathrm{m}^{2}$ with water rate of $150 \mathrm{ml} / \mathrm{min}$, can be approximated as $79.8 \%, 77.3 \%$ and $75.2 \%$, respectively.

\subsection{Overall efficiency and comparisons with other relevant PVT collectors}

Although the previous subsections show that both the electric and thermal efficiencies of the BIPVT panel increase with an increased water flowrate, it shows from Table 1 that the relative increase in the outlet water temperature compared to the inlet water temperature actually decreases. For customers who want to utilize a larger amount of hotter water through the BIPVT, they may need to decrease the water flowrate and thus sacrifice the electricity gain, and vice versa. In this sense, a desired water flowrate can be adjusted based on a customer's need in terms of the harvested heat energy collected by the warm water or the enhanced electricity generation efficiency from the PV module. Figure 12 provides a general comparison of the relative increase in the outlet water temperature compared to the inlet water temperature, thermal efficiency and electric efficiency provided by the present BIPVT panel at different water flowrates under different irradiance intensities. 


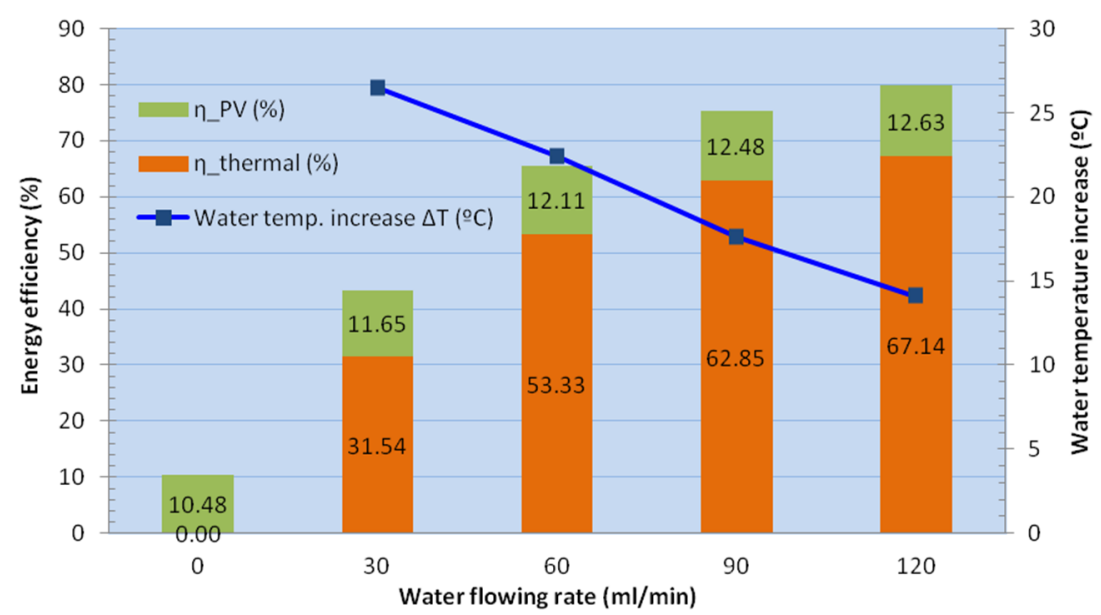

(a) $620 \mathrm{~W} / \mathrm{m}^{2}$

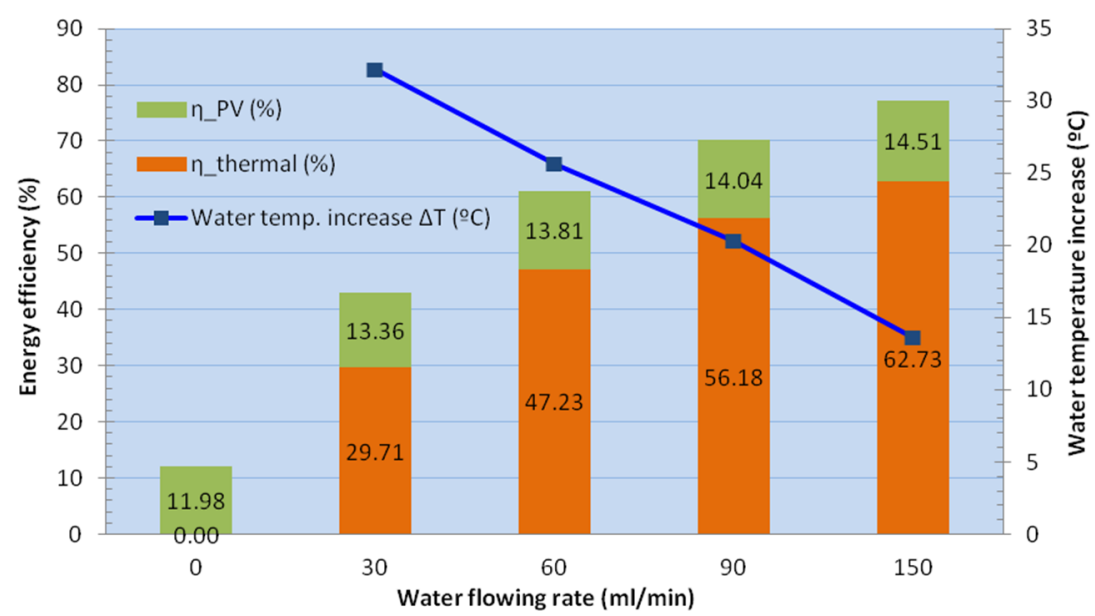

(b) $800 \mathrm{~W} / \mathrm{m}^{2}$

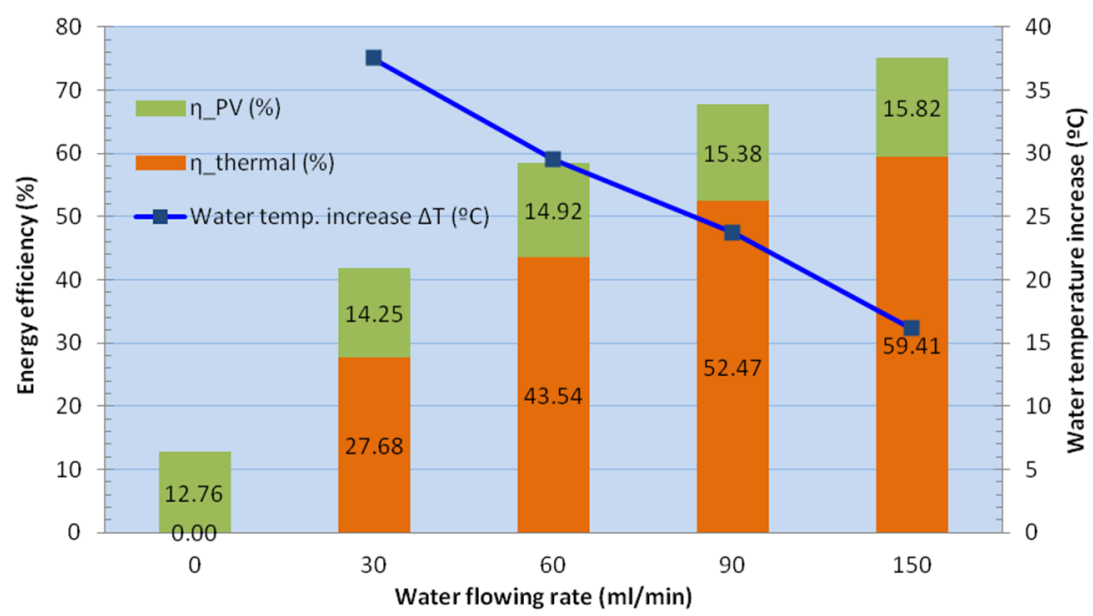

(c) $1000 \mathrm{~W} / \mathrm{m}^{2}$

Figure 12 Increased water temperature, thermal and electricity conversion efficiencies of the BIPVT at different solar irradiance: (a) $620 \mathrm{~W} / \mathrm{m}^{2}$; (b) $800 \mathrm{~W} / \mathrm{m}^{2}$, and; (c) $1000 \mathrm{~W} / \mathrm{m}^{2}$. 
The comparison of the electric and thermal efficiencies of the present BIPVT roofing panel with other typical PVTs or BIPVTs with water as the heat transfer fluid is presented in Table 3. Note that all the studies compared in Table 3 didn't taking into account the energy needed for operating pumps in calculating the different efficiencies. Overall, the literature contains many more performance evaluations of various PVTs than that of BIPVTs. Thus, only some of them with similar features to the presented BIPVT panel were collected in this comparison. Among those PVTs compared, the PVT water collector proposed by Fudholi et al. [51], which consists of a combined PV module and a spiral flow absorber, exhibited the highest performance in the current literature. It was reported that this absorber produced a PVT efficiency of $68.4 \%$, a PV efficiency of $13.8 \%$, and a thermal efficiency of $54.6 \%$ at a solar radiation level of $800 \mathrm{~W} / \mathrm{m}^{2}$ and mass flow rate of $0.041 \mathrm{~kg} / \mathrm{s}$.

For the BIPVTs, Chow et al. [52] designed a centralized photovoltaic and hot water collector wall system and conducted relevant experimental studies under different operating modes at different seasons. The average radiance of six different operation modes ranges from $8.3 \mathrm{MJ} / \mathrm{m}^{2}$ to $12.8 \mathrm{MJ} / \mathrm{m}^{2}$ were investigated. A water consumption of $0.46 \mathrm{~m}^{3} /$ day was chosen in their experiment, which virtually made the water storage tank performed as a daily tank. Their test results showed that the thermal efficiency and the corresponding electricity conversion efficiency found by statistical analysis were $38.9 \%$ and $8.56 \%$, respectively. Corbin and Zhai [31] developed a prototype BIPVT roof collector and conducted an experimentally validated computational fluid dynamics (CFD) simulation. The heat collection efficiency was measured from the temperature difference between the outlet and inlet water temperatures, while the electrical efficiency was indirectly calculated by considering the cell efficiency loss due to the operating temperature increase (hereby denoted as indirect method). Their reported results showed that their BIPVT roof collector was able to provide a thermal and combined (thermal plus electrical) efficiencies of $19 \%$ and 34.9\%, respectively. Anderson et al. [29] designed a prototype BIPVT water collector which was integrated to the standing seam or toughed sheet roof. A modified Hottel-Whillier-Bliss equation was applied to analyze the thermal and electrical performances of the BIPVT. In calculating the thermal efficiency, a packing factor of $40 \%$ was applied, while the electrical efficiency was calculated by the indirect method where an electrical efficiency loss factor $0.5 \% /{ }^{\circ} \mathrm{C}$ was used. Their results showed that the thermal and electric efficiencies of the BIPVT roof collector were within the ranges of $12.5 \sim 14 \%$ and $40 \sim 60 \%$, respectively. Kim et al [53] developed a water-type unglazed BIPVT collector. Based on the similar expressions of Eqs. (2) and (4) in this study, the thermal and electrical efficiencies of their BIPVT under a clear day from 9 a.m. to 3 p.m were calculated, respectively. It was reported that the average thermal and electrical efficiencies were $30 \%$ and $17 \%$, respectively.

Bases on the spiral flow absorber designed in [51], Ibrahim et al. [35] further developed a BIPVT roof system with the spiral flow copper absorber attached at the bottom of PV modules on the roof. The collector was assumed as a flat plate collector with single glazing sheet. The thermal performance of the PVT unit was evaluated by the Hottel-Whillier equations while the electrical efficiency was calculated by the indirect method with an electrical efficiency loss factor of $0.45 \% /{ }^{\circ} \mathrm{C}$. From the energy analysis at a mass flow rate of $0.027 \mathrm{~kg} / \mathrm{s}$ and average solar radiation of $690 \mathrm{~W} / \mathrm{m}^{2}$, it was found that the average electric and thermal efficiencies of the BIPVT roof were $10.8 \%$ and $48 \%$, respectively.

Table 3 Comparison of panel efficiencies among different studies

\begin{tabular}{|c|c|c|c|c|c|}
\hline Study & & Radiation & $\eta_{p v}$ & $\eta_{\text {thermal }}$ & $\eta_{P V T}$ \\
\hline
\end{tabular}




\begin{tabular}{|c|c|c|c|c|c|c|}
\hline & $\begin{array}{c}\text { BIPVT } \\
(\text { yes/no })\end{array}$ & $\begin{array}{c}\text { Daily } \\
\left(\mathrm{MJ} / \mathrm{m}^{2}\right)\end{array}$ & $\begin{array}{c}\text { Transient } \\
\left(\mathrm{W} / \mathrm{m}^{2}\right)\end{array}$ & $\begin{array}{c}(\%) \\
(\%)\end{array}$ & $(\%)$ \\
\hline Huang et al. [54] & No & $6.6 \sim 15.9$ & - & $\sim 9$ & $12.2 \sim 44.5$ & $21.2 \sim 53.5$ \\
\hline He et al. [23] & No & $10.5 \sim 19.8$ & - & $3.9 \sim 5.4$ & $28.8 \sim 52.0$ & $32.7 \sim 57.4$ \\
\hline Chow et al. [55] & No & $12.8 \sim 22.2$ & - & $9.9 \sim 10.2$ & $45-48$ & $54.9 \sim 58.2$ \\
\hline Ji et al. [56] & No & $9.3 \sim 21.2$ & - & $9.4 \sim 10.3$ & $34.7 \sim 56.9$ & $40.6 \sim 63.1$ \\
\hline Fudholi et al. [51] & No & - & 800 & 13.8 & 54.6 & 68.4 \\
\hline Chow et al. [52] & Yes & $8.3 \sim 12.8$ & - & 8.56 & 38.9 & 47.46 \\
\hline Corbin and Zhai [31] & Yes & - & $1000^{*}$ & 15.9 & 19 & 34.9 \\
\hline Anderson et al [29] & Yes & Daily average & - & $12.5-14$ & $40-60 *$ & - \\
\hline Kim et al [53] & Yes & Daily average & - & $\sim 17$ & $\sim 30$ & $\sim 47$ \\
\hline Ibrahim et al [35] & Yes & - & 690 & $10.4-11.3$ & $45-51$ & $55-62$ \\
\hline Present study & Yes & - & 620 & 12.6 & 67.1 & 79.7 \\
\hline Present study & Yes & - & 800 & 14.5 & 62.7 & 77.2 \\
\hline Present study & Yes & - & 1000 & 15.8 & 59.4 & 75.2 \\
\hline
\end{tabular}

* Experimentally validated computational fluid dynamics (CFD) simulation

**A packing factor of $40 \%$ was applied to the collector.

From the comparisons shown in Table 3, the presented BIPVT panel in this study is able to harvest solar irradiance more efficiently in form of electricity and heat than most PVT or BIPVT technologies currently available in the literature. Because of the ability to control temperatures through the water flow, the PV modules can work at lower temperatures in the summer time, leading to a higher efficiency for PV utilization. Furthermore, due to the temperature control on the roof, better thermal comfort in the building can be achieved and therefore the energy demand for cooling can be reduced in the summer time. Moreover, the warm water flow can be applied to remove frost or ice on the roof in winter time, thus further restore and enhance solar energy utilization. In addition, as shown in Table 1 and Table 2, the temperature increase of the collected water, the useful collected heat, and the increased PV efficiency vary from the water flowing rate and the irradiance levels. This provides customers with much flexibility to adjust the water flowing rate to meet their specific requirements.

\section{Summaries and conclusions}

In this study, a building integrated photovoltaic-thermal multifunctional roofing system has been developed to efficiently harvest solar energy in the form of PV electricity as well as heat energy through the collection of warm water. As an essential component of the multifunctional building envelope, a recently developed functionally graded material (FGM) panel was successfully integrated into the BIPVT panel. The FGM layer gradually transits material phases 
from well-conductive side (aluminum dominated) to another highly insulated side (HDPE dominated). Due to the high thermal conductivity of the upper part of the FGM, the heat in the PV cells can be immediately transferred into the FGM and then captured by the cool water flowing in all directions through the embedded tubes. Thus the elevated operation temperature in the PV cells can be easily cooled down and as a consequence the PV efficiency can be considerably enhanced.

The proposed BIPVT panel can be integrated into building skin with relevant system components such as water circulation, flow control, and heat storage. However, this technology is not a simple superposition of the necessary materials and costs, but it provides a viable solution to significantly increase the efficiency and the overall energy utilization while alleviating the disadvantages of a single approach. It enables heat harvesting while improving the efficiency of the PV modules by controlling the temperature. The electricity can be directly transmitted to the grid, while the heat can be stored or directly used. If the heat is directly used, it can serve as an indoor or external heat supply for many possible applications including floor heating, swimming pools, and solar vegetable gardens. This system can be used for the generation of electricity and heat for both residential and commercial buildings, which in turn reduces the heating and cooling costs. The performances of the prototype BIPVT panel in terms of its thermal efficiency via warm water collection and PV efficiency via the output electricity have also been evaluated in the laboratory. Test results showed that

- The increased temperature of the collected water by the BIPVT can be as high as $37.5^{\circ} \mathrm{C}$ at an irradiance of $1000 \mathrm{~W} / \mathrm{m}^{2}$ with a relatively low flowrate at $30 \mathrm{ml} / \mathrm{min}$, and that the decreased surface temperature of the BIPVT can be as high as $32^{\circ} \mathrm{C}$ when the flowrate is increased to 150 $\mathrm{ml} / \mathrm{min}$. It is expected that, as the water flowrate increases, the BIPVT surface temperature will further decrease.

- At a water flowrate of $150 \mathrm{ml} / \mathrm{min}$, the output electricity energy $E_{p v}$ reaches $32.96 \mathrm{~W}$ and $44.91 \mathrm{~W}$ and the PV efficiency $\eta_{p v}$ reaches $14.51 \%$ and $15.82 \%$ under solar irradiance of 800 and $1000 \mathrm{~W} / \mathrm{m}^{2}$, respectively. The PV efficiency is also enhanced by $21.1 \%$ and $24.0 \%$ for those two solar irradiances respectively, compared with the case when no water flow is introduced.

- At an introduced water flowrate of $150 \mathrm{ml} / \mathrm{min}$, the total energy efficiency $\left(\eta_{T}=\eta_{\text {thermal }}+\right.$ $\eta_{p v}$ ) of the presented BIPVT roofing panel has been evaluated to be $79.8 \%, 77.3 \%$ and $75.2 \%$ under solar irradiances of $620 \mathrm{~W} / \mathrm{m}^{2}, 800 \mathrm{~W} / \mathrm{m}^{2}$ and $1000 \mathrm{~W} / \mathrm{m}^{2}$, respectively.

Overall, the test results demonstrate that significant energy conversion efficiency improvement can be achieved for both electricity generation and heat collection by the presented BIPVT roofing panel. From the comparisons of the present BIPVT with other relevant technologies, it was found that the BIPVT panel in this study is able to harvest solar irradiance more efficiently in form of electricity and heat than most PVT or BIPVT technologies currently available in the literature. Because of the ability to control temperatures through the water flow, the PV modules can work at lower temperatures in the summer time, leading to a higher efficiency for PV utilization. Furthermore, due to the temperature control on the roof, better thermal comfort in the building can be achieved and therefore the energy demand for cooling can be reduced in the summer time. Moreover, the warm water flow can be applied to remove frost or ice on the roof in winter time, thus further restore and enhance solar energy utilization. In addition, the present BIPVT provides customers with much flexibility to adjust the water flowing rate to meet their specific requirements. 
It's worthy to note that the overall efficiencies of the BIPVT panel presented in this study were evaluated based on instantaneous measurements within a certain period of time from a wellcontrolled laboratory testing condition. In order to evaluate the long-term life cycle efficiency of the panel, more detailed parameters of the final product of the BIPVT such as emittance of the panel after protective layer above the PV layer is applied, overall convection heat transfer coefficient, and operating climate parameters during data collection period, shall be measured through massive field tests, which will be reported in our future study.

\section{Acknowledgement}

This work is sponsored by the National Science Foundation CMMI 0954717, whose supports are gratefully acknowledged. The authors appreciate the contributions from Mr. Yuda Sun, Mr. Xin He, Mr. Joao Silva, and Mr. Rodolfo Kusma on the laboratory testing and Dr. Daniel Hochstein on manuscript preparation. The authors also appreciate the support of the Henry Mitchell Weitzner Research Fund, which has been and will be used in his research of roofing materials for solar energy applications and technologies.

\section{References}

[1] 2011, "Buildings Energy Data Book, U.S. DOE" [Online]. Available: http://buildingsdatabook.eren.doe.gov/ChapterIntro1.aspx. [Accessed: 07-Jul-2014].

[2] Chen, F. L., Yang, D. J., and Yin, H. M., 2015, “Application,” Semiconductor Materials for Solar Photovoltaic Cells, Springer International Publishing.

[3] Eiffert, P., 2000, Building-Integrated Photovoltaic Designs for Commercial and Institutional Structures: A Sourcebook for Architects, DIANE Publishing, National Renewable Energy Laboratory.

[4] Jelle, B. P., Breivik, C., and Drolsum Røkenes, H., 2012, "Building integrated photovoltaic products: A state-of-the-art review and future research opportunities," Solar Energy Materials and Solar Cells, 100, pp. 69-96.

[5] Zogou, O., and Stapountzis, H., 2011, "Energy analysis of an improved concept of integrated PV panels in an office building in central Greece," Applied Energy, 88(3), pp. 853-866.

[6] Jelle, B. P., and Breivik, C., 2012, "State-of-the-art Building Integrated Photovoltaics," Energy Procedia, 20, pp. 68-77.

[7] Chae, Y. T., Kim, J., Park, H., and Shin, B., 2014, "Building energy performance evaluation of building integrated photovoltaic (BIPV) window with semi-transparent solar cells," Applied Energy, 129, pp. 217-227.

[8] Archibald, J., 1999, "Building Integrated Solar Thermal Roofing Systems-History, Current Status and Future Promise," In Proceedings of the Solar Conference.

[9] Lamnatou, C., Mondol, J. D., Chemisana, D., and Maurer, C., 2015, "Modelling and simulation of Building-Integrated solar thermal systems: Behaviour of the coupled building/system configuration," Renewable and Sustainable Energy Reviews, 48, pp. 178191.

[10] Buker, M. S., and Riffat, S. B., 2015, "Building integrated solar thermal collectors - A review," Renewable and Sustainable Energy Reviews, 51, pp. 327-346. 
[11] Chow, T. T., Hand, J. W., and Strachan, P. A., 2003, "Building-integrated photovoltaic and thermal applications in a subtropical hotel building," Applied Thermal Engineering, 23(16), pp. 2035-2049.

[12] Pantic, S., Candanedo, L., and Athienitis, A. K., 2010, "Modeling of energy performance of a house with three configurations of building-integrated photovoltaic/thermal systems," Energy and Buildings, 42(10), pp. 1779-1789.

[13] Athienitis, A. K., Bambara, J., O'Neill, B., and Faille, J., 2011, "A prototype photovoltaic/thermal system integrated with transpired collector," Solar Energy, 85(1), pp. 139-153.

[14] Vats, K., and Tiwari, G. N., 2012, "Energy and exergy analysis of a building integrated semitransparent photovoltaic thermal (BISPVT) system,” Applied Energy, 96, pp. 409-416.

[15] Agrawal, B., and Tiwari, G. N., 2010, "Optimizing the energy and exergy of building integrated photovoltaic thermal (BIPVT) systems under cold climatic conditions," Applied Energy, 87(2), pp. 417-426.

[16] Agrawal, B., and Tiwari, G. N., 2011, Building Integrated Photovoltaic Thermal Systems: For Sustainable Developments, Royal Society of Chemistry.

[17] Gueymard, C. A., and duPont, W. C., 2009, "Spectral effects on the transmittance, solar heat gain, and performance rating of glazing systems," Solar Energy, 83(6), pp. 940-953.

[18] Parida, B., Iniyan, S., and Goic, R., 2011, "A review of solar photovoltaic technologies," Renewable and Sustainable Energy Reviews, 15(3), pp. 1625-1636.

[19] Sun, L., Lu, L., and Yang, H., 2012, "Optimum design of shading-type building-integrated photovoltaic claddings with different surface azimuth angles," Applied Energy, 90(1), pp. 233-240.

[20] Chow, T. T., 2010, “A review on photovoltaic/thermal hybrid solar technology," Applied Energy, 87(2), pp. 365-379.

[21] Jelle, B. P., 2015, "Building Integrated Photovoltaics: A Concise Description of the Current State of the Art and Possible Research Pathways," Energies, 9(1), p. 21.

[22] Muller, J., Hinken, D., Blankemeyer, S., Kohlenberg, H., Sonntag, U., Bothe, K., Dullweber, T., Kontges, M., and Brendel, R., 2015, "Resistive Power Loss Analysis of PV Modules Made From Halved 15.6 \#x2009; \#x00D7; \#x2009;15.6 cm2 Silicon PERC Solar Cells With Efficiencies up to 20.0 \#x0025;", IEEE Journal of Photovoltaics, 5(1), pp. 189-194.

[23] He, W., Chow, T.-T., Ji, J., Lu, J., Pei, G., and Chan, L., 2006, "Hybrid photovoltaic and thermal solar-collector designed for natural circulation of water," Applied Energy, 83(3), pp. 199-210.

[24] 2015, "Solar Panel Temperature - Facts and Tips" [Online]. Available: http://www.solarfacts-and-advice.com/solar-panel-temperature.html. [Accessed: 22-Jul-2015].

[25] Skoplaki, E., and Palyvos, J. A., 2009, "On the temperature dependence of photovoltaic module electrical performance: A review of efficiency/power correlations," Solar Energy, 83(5), pp. 614-624.

[26] Nagano, K., Mochida, T., Shimakura, K., Murashita, K., and Takeda, S., 2003, "Development of thermal-photovoltaic hybrid exterior wallboards incorporating PV cells in and their winter performances," Solar Energy Materials and Solar Cells, 77(3), pp. 265-282.

[27] Yang, T., and Athienitis, A. K., 2014, “A study of design options for a building integrated photovoltaic/thermal (BIPV/T) system with glazed air collector and multiple inlets," Solar Energy, 104, pp. 82-92. 
[28] Yang, T., and Athienitis, A. K., 2015, "Experimental investigation of a two-inlet air-based building integrated photovoltaic/thermal (BIPV/T) system," Applied Energy, 159, pp. 70-79.

[29] Anderson, T. N., Duke, M., Morrison, G. L., and Carson, J. K., 2009, "Performance of a building integrated photovoltaic/thermal (BIPVT) solar collector," Solar Energy, 83(4), pp. 445-455.

[30] Chow, T. T., Chan, A. L. S., Fong, K. F., Lin, Z., He, W., and Ji, J., 2009, “Annual performance of building-integrated photovoltaic/water-heating system for warm climate application," Applied Energy, 86(5), pp. 689-696.

[31] Corbin, C. D., and Zhai, Z. J., 2010, "Experimental and numerical investigation on thermal and electrical performance of a building integrated photovoltaic-thermal collector system," Energy and Buildings, 42(1), pp. 76-82.

[32] Ghani, F., Duke, M., and Carson, J. K., 2012, "Effect of flow distribution on the photovoltaic performance of a building integrated photovoltaic/thermal (BIPV/T) collector," Solar Energy, 86(5), pp. 1518-1530.

[33] Chen, K., Han, H. J., Jeon, Y. I., Lim, S. H., and Kim, W. W., 2010, "New developments in illumination, heating and cooling technologies for energy-efficient buildings," Energy, 35, pp. $2647-2653$.

[34] Kumar, A., Baredar, P., and Qureshi, U., 2015, "Historical and recent development of photovoltaic thermal (PVT) technologies," Renewable and Sustainable Energy Reviews, 42, pp. $1428-1436$.

[35] Ibrahim, A., Fudholi, A., Sopian, K., Othman, M. Y., and Ruslan, M. H., 2014, "Efficiencies and improvement potential of building integrated photovoltaic thermal (BIPVT) system," Energy Conversion and Management, 77, pp. 527-534.

[36] Buker, M. S., Mempouo, B., and Riffat, S. B., 2015, "Experimental investigation of a building integrated photovoltaic/thermal roof collector combined with a liquid desiccant enhanced indirect evaporative cooling system," Energy Conversion and Management, 101, pp. 239254.

[37] Ibrahim, A., Othman, M. Y., Ruslan, M. H., Mat, S., and Sopian, K., 2011, "Recent advances in flat plate photovoltaic/thermal (PV/T) solar collectors," Renewable and Sustainable Energy Reviews, 15(1), pp. 352-365.

[38] Yin, H. M., Yang, D. J., Kelly, G., and Garant, J., 2013, "Design and performance of a novel building integrated PV/thermal system for energy efficiency of buildings," Solar Energy, 87, pp. 184-195.

[39] Yang, D., and Yin, H., 2011, "Energy Conversion Efficiency of a Novel Hybrid Solar System for Photovoltaic, Thermoelectric, and Heat Utilization," IEEE Transactions on Energy Conversion, 26(2), pp. 662-670.

[40] Yang, D. J., Yuan, Z. F., Lee, P. H., and Yin, H. M., 2012, "Simulation and experimental validation of heat transfer in a novel hybrid solar panel," International Journal of Heat and Mass Transfer, 55(4), pp. 1076-1082.

[41] Chen, F. L., He, X., and Yin, H. M., 2016, "Manufacture and multi-physical characterization of aluminum/high-density polyethylene functionally graded materials for green energy building envelope applications," Energy and Buildings, 116, pp. 307-317.

[42] Kieback, B., Neubrand, A., and Riedel, H., 2003, "Processing techniques for functionally graded materials," Materials Science and Engineering: A, 362(1-2), pp. 81-106. 
[43] Müller, E., Drašar, Č., Schilz, J., and Kaysser, W. A., 2003, "Functionally graded materials for sensor and energy applications," Materials Science and Engineering: A, 362(1-2), pp. 17-39.

[44] Lee, P., and Yin, H., 2015, "Size Effect on Functionally Graded Material Fabrication by Sedimentation," Journal of Nanomechanics and Micromechanics, 5(2), p. A4014008.

[45] Yang, L., and Yin, H., 2014, "Parametric study of particle sedimentation by dissipative particle dynamics simulation," Phys. Rev. E, 90(3), p. 33311.

[46] Council, I. C., 2014, 2015 International Building Code, ICC.

[47] Duffie, J. A., and Beckman, W. A., 2006, Solar engineering of thermal processes, Wiley, New York, Wiley, New York.

[48] Prakash, G. \&, and Garg, H. P., 2000, Solar Energy: Fundamentals and Applications, Tata McGraw-Hill Education.

[49] Morgan, M. J., Jakovidis, G., and McLeod, I., 1994, "An experiment to measure the I-V characteristics of a silicon solar cell," Physics Education, 29(4), pp. 252-254.

[50] Chander, S., Purohit, A., Sharma, A., Arvind, Nehra, S. P., and Dhaka, M. S., 2015, "A study on photovoltaic parameters of mono-crystalline silicon solar cell with cell temperature," Energy Reports, 1, pp. 104-109.

[51] Fudholi, A., Sopian, K., Yazdi, M. H., Ruslan, M. H., Ibrahim, A., and Kazem, H. A., 2014, "Performance analysis of photovoltaic thermal (PVT) water collectors," Energy Conversion and Management, 78, pp. 641-651.

[52] Chow, T. T., He, W., and Ji, J., 2007, "An experimental study of façade-integrated photovoltaic/water-heating system," Applied Thermal Engineering, 27(1), pp. 37-45.

[53] Kim, J.-H., Park, S.-H., Kang, J.-G., and Kim, J.-T., 2014, "Experimental Performance of Heating System with Building-integrated PVT (BIPVT) Collector,” Energy Procedia, 48, pp. 1374-1384.

[54] Huang, B. J., Lin, T. H., Hung, W. C., and Sun, F. S., 2001, "Performance evaluation of solar photovoltaic/thermal systems," Solar Energy, 70(5), pp. 443-448.

[55] Chow, T. T., Ji, J., and He, W., 2006, "Photovoltaic-Thermal Collector System for Domestic Application,” J. Sol. Energy Eng, 129(2), pp. 205-209.

[56] Ji, J., Lu, J.-P., Chow, T.-T., He, W., and Pei, G., 2007, "A sensitivity study of a hybrid photovoltaic/thermal water-heating system with natural circulation," Applied Energy, 84(2), pp. 222-237. 